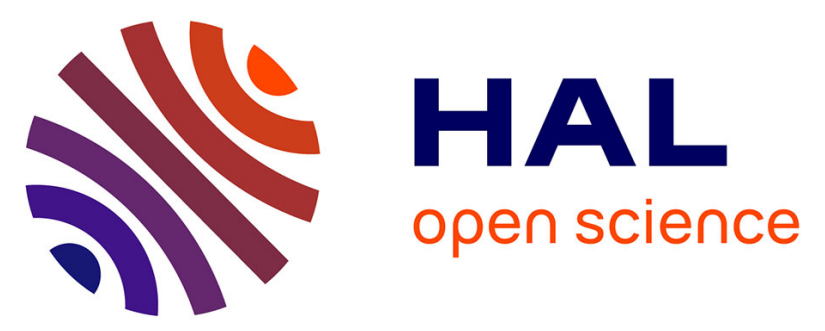

\title{
3D numerical modeling of mantle flow, crustal dynamics and magma genesis associated with slab roll-back and tearing: The eastern Mediterranean case \\ Armel Menant, Pietro Sternai, Laurent Jolivet, Laurent Guillou-Frottier, Taras Gerya
}

\section{To cite this version:}

Armel Menant, Pietro Sternai, Laurent Jolivet, Laurent Guillou-Frottier, Taras Gerya. 3D numerical modeling of mantle flow, crustal dynamics and magma genesis associated with slab roll-back and tearing: The eastern Mediterranean case. Earth and Planetary Science Letters, 2016, 442, pp.93-107. 10.1016/j.epsl.2016.03.002 . insu-01288706

\section{HAL Id: insu-01288706 \\ https://hal-insu.archives-ouvertes.fr/insu-01288706}

Submitted on 16 Mar 2016

HAL is a multi-disciplinary open access archive for the deposit and dissemination of scientific research documents, whether they are published or not. The documents may come from teaching and research institutions in France or abroad, or from public or private research centers.
L'archive ouverte pluridisciplinaire HAL, est destinée au dépôt et à la diffusion de documents scientifiques de niveau recherche, publiés ou non, émanant des établissements d'enseignement et de recherche français ou étrangers, des laboratoires publics ou privés.

\section{(ㅇ)(1) $\$$}

Distributed under a Creative Commons Attribution - NonCommercial - NoDerivatives 44.0 
1 3D numerical modeling of mantle flow, crustal dynamics and magma genesis associated with slab

2 roll-back and tearing: the eastern Mediterranean case

3

4 Armel Menant ${ }^{\mathrm{a}, \mathrm{b}, \mathrm{c}, \mathrm{d}, *}$, Pietro Sternai ${ }^{\mathrm{e}}$, Laurent Jolivet ${ }^{\mathrm{a}, \mathrm{b}, \mathrm{c}}$, Laurent Guillou-Frottier ${ }^{\mathrm{b}, \mathrm{a}, \mathrm{c}}$, Taras

5 Gerya $^{\mathrm{f}}$

6

$7 \quad{ }^{a}$ Univ d'Orléans, ISTO, UMR 7327, 45071 Orléans, France

8

${ }^{b}$ BRGM, ISTO, UMR 7327, BP 36009, 45060 Orléans, France

$9 \quad{ }^{c}$ CNRS/INSU, ISTO, UMR 7327, 45071 Orléans, France

${ }^{d}$ Now at the Laboratoire des Fluides Complexes et leurs Réservoirs, Université de Pau et 11 des Pays de l'Adour, UMR 5150, Pau, France

${ }^{e}$ Department of Earth Sciences, University of Cambridge, Cambridge, UK

${ }^{f}$ Institute of Geophysics - Swiss Federal Institute of Technology (ETH), Zürich,

Switzerland

15

* Corresponding author: Armel Menant - Laboratoire des Fluides Complexes et leurs

17 Réservoirs

Université de Pau et des Pays de l'Adour

(armel.menant@univ-pau.fr) 


\section{Abstract}

Interactions between subduction dynamics and magma genesis have been intensely investigated, resulting in several conceptual models derived from geological, geochemical and geophysical data. To provide physico-chemical constraints on these conceptual models, selfconsistent numerical simulations containing testable thermo-mechanical parameters are required, especially considering the three-dimensional (3D) natural complexity of subduction systems. Here, we use a 3D high-resolution petrological and thermo-mechanical numerical model to quantify the relative contribution of oceanic and continental subduction/collision, slab roll-back and tearing to magma genesis and transport processes. Our modeling results suggest that the space and time distribution and composition of magmas in the overriding plate is controlled by the $3 \mathrm{D}$ slab dynamics and related asthenospheric flow. Moreover, the decrease of the bulk lithospheric strength induced by mantle- and crust-derived magmas promotes the propagation of strike-slip and extensional fault zones through the overriding crust as response to slab roll-back and continental collision. Reduction of the lithosphere/asthenosphere rheological contrast by lithospheric weakening also favors the transmission of velocities from the flowing mantle to the crust. Similarities between our modeling results and the late Cenozoic tectonic and magmatic evolution across the eastern Mediterranean region suggest an efficient control of mantle flow on the magmatic activity in this region, which in turn promotes lithospheric deformation by mantle drag via melt-induced weakening effects.

\section{Keywords}

3D numerical modeling, subduction-related magmatism, slab roll-back, slab tearing, asthenospheric flow, lithospheric deformation 


\section{Introduction}

Arc magmatism is one of the most typical surface expressions of subduction dynamics tracking physico-chemical processes from the upper mantle to the crust [Arculus, 1994]. It is broadly accepted that the genesis of these magmas is dominated by partial melting of a hydrated mantle wedge source, as the result of the $\mathrm{H}_{2} \mathrm{O}$ release from the subducting oceanic lithosphere [Arculus, 1994; Grove et al., 2006]. These primary mafic magmas then ascend through the mantle, reaching the base of the overriding crust where they can be retained in the melting assimilation storage and homogenization (MASH) zone [Hildreth and Moorbath, 1988]. During their storage and their subsequent ascent up to the upper crust, these magmas undergo some degrees of fractionation and crustal assimilation, which provide the typical calc-alkaline magmatic trend. To reach a coherent understanding of the interactions between subduction dynamics and magma genesis, numerical experiments have been performed involving mechanical, thermal and petrological constraints $[H u w$ Davies and von Blanckenburg, 1995; Nikolaeva et al., 2008; Zhu et al., 2009, 2013; Gerya and Meilick, 2011; Bouilhol et al., 2015]. However, in subduction environment involving slab roll-back and tearing, the 3D effects of slab dynamics and related asthenospheric flow on the threedimensional (3D) space and time distribution and composition of magmas have been most often assessed by conceptual models [e.g. Pe-Piper and Piper, 2006; Dilek and Altunkaynak, 2009; Ersoy and Palmer, 2013; Jolivet et al., 2015].

In 3D oceanic-continental subduction system involving slab roll-back and tearing, particular attention has been given to the control of subduction dynamics and related asthenospheric flow on lithospheric deformation without considering the role of magmatic processes [Jadamec and Billen, 2010; Li et al., 2013; Capitanio, 2014; Duretz et al., 2014; Magni et al., 2014; Sternai et al., 2014]. Rheological weakening effect of magmas resulting from the partial melting of the upper mantle and the crust has, however, major consequences 
on lithospheric-scale tectonics [Gerya and Meilick, 2011], which need to be tested across complex 3D subduction system.

Here we use a 3D high-resolution petrological and thermo-mechanical numerical geodynamic model to assess (1) the role of subduction dynamics involving slab roll-back and tearing processes on the magmatic activity within the overriding lithosphere and (2) the weakening effect of magmas on the lithospheric deformation. The numerical setup accounts for experimentally calibrated non-Newtonian visco-plastic rheologies and physico-chemical processes, such as slab dehydration, fluid transport, partial melting, melt extraction and crustal growth [e.g. Nikolaeva et al., 2008; Zhu et al., 2013]. Modeling results suggest that slab dynamics and related asthenospheric flow affect the genesis, transport and emplacement of magmatic bodies both in the arc and back-arc domain and that such melts weaken the lithosphere, promoting lithospheric deformation and its coupling with asthenospheric flow. Our results are then compared to observations from the eastern Mediterranean region, where the late Cenozoic evolution of the subduction zone including slab roll-back and tearing processes and associated magmatism is relatively well constrained (Fig. 1) [e.g. Jolivet and Faccenna, 2000; Pe-Piper and Piper, 2006; Dilek and Altunkaynak, 2009; Ersoy and Palmer, 2013; Jolivet et al., 2013].

\section{Late Cenozoic evolution of the eastern Mediterranean subduction zone}

Since the Mesozoic, the geodynamic evolution of the Mediterranean realm is characterized by the subduction and/or collision of successive oceanic and continental lithospheres, governed by the Africa-Eurasia convergence [Stampfli and Borel, 2002; Menant et al., 2016]. Since the latest Eocene-early Oligocene (i.e. 35-30 Ma), increasing rate of slab retreat has resulted in the opening of back-arc basins, such as in the eastern Mediterranean region where the Hellenic southward slab roll-back led to the opening of the Aegean domain [Jolivet and 
Faccenna, 2000]. In this extensional context, medium- to high-temperature rocks were exhumed as several metamorphic core complexes (MCCs), such as in the Rhodope massif, the Cyclades and the Menderes massif (Fig. 1) [Lister et al., 1984; Bozkurt and Oberhänsli, 2001; Vanderhaeghe, 2004; Brun and Sokoutis, 2007; Jolivet et al., 2013]. At the same time, subduction and collision of the Arabian plate with the southern margin of the Tauride belt took place further east (Fig. 1c) [Jolivet and Faccenna, 2000]. The present-day kinematics of this region is characterized by an overall counterclockwise rotation of the surface velocity vectors as recorded by GPS measurements (Fig. 2a) [Reilinger et al., 2006; Le Pichon and Kreemer, 2010] controlled by the westward extrusion of Anatolia, which is mainly accommodated by the North Anatolian Fault (NAF) [Şengör et al., 2005].

At $\sim 150 \mathrm{~km}$-depth, tomographic models for the eastern Mediterranean region show trenchparallel variations in seismic velocity, with low-velocity anomalies located in eastern and western Anatolia and interpreted as major break-off or tears in the slab that displays a highvelocity anomaly (see star symbols in Fig. 2b) [de Boorder et al., 1998; Wortel and Spakman, 2000; Li et al., 2008]. The complex geometry of the subducting lithosphere thus resulted in a complex mantle convection pattern including both poloidal and toroidal flows [Faccenna and Becker, 2010], the latter having been partly imaged by $S K S$ splitting anisotropy (Fig. 2b) [Paul et al., 2014].

Integrated in this complex tectonic frame, magmatic occurrences show a specific spatial and temporal distribution associated with variable petrological and geochemical composition [Menant et al., 2016]. Since the Oligocene (i.e. 34-23 Ma), high-potassic calc-alkaline to shoshonitic magmatism was progressively emplaced southward from the Rhodope massif to the Cyclades and the Menderes massif, associated with the exhumation of MCCs (Figs. 1a, c) [Pe-Piper and Piper, 2006; Dilek and Altunkaynak, 2009; Ersoy and Palmer, 2013]. In addition to this first-order migration, a secondary southwestward migration of the magmatic 
activity is recorded during the Miocene (i.e. 23-5 Ma) from the Menderes massif to the Cyclades (Fig. 1a) [Jolivet et al., 2015]. Evolution of geochemical and isotopic composition of this magmatism suggests an increase of mantle source component relative to the crustal source component [Keskin, 2003; Dilek and Altunkaynak, 2009; Ersoy and Palmer, 2013; Jolivet et al., 2015], finally producing alkaline magmas with a major depleted asthenospheric source component [Ersoy and Palmer, 2013]. In eastern Anatolia, a wide late MioceneQuaternary volcanic province was also emplaced with composition evolving from highpotassic calc-alkaline to alkaline (Fig. 1c) [Keskin, 2003].

\section{Numerical modeling}

In this section we describe the modeling approach and the initial reference model setup and then outline the main objectives of the parametric study.

\subsection{Modeling approach and setup}

We use the wealth of observations from the eastern Mediterranean region to design and calibrate numerical experiments that could be qualitatively and quantitatively compared to the first order evolution of this region during the late Cenozoic. We stress, however, that the main objective of our work is to investigate the $3 \mathrm{D}$ effects of slab retreat and tearing on magmatism and we do not claim that our models provide an exhaustive description of geodynamics across the area. As such, results may also be representative of other regions similarly characterized by fast evolving narrow subduction zones involving lateral variations of the subducting material (e.g. central and western Mediterranean region, southeastern Asia).

Numerical modeling was performed using the code I3ELVIS, like in other recent studies [Zhu et al., 2009, 2013; Li et al., 2013; Duretz et al., 2014; Sternai et al., 2014]. The code solves the mass, momentum and heat conservation equations based on a conservative finite- 
difference scheme combined with a marker-in-cell technique and includes non-Newtonian visco-plastic rheologies (Table S1) [Gerya and Yuen, 2007]. In addition, this code accounts for physico-chemical processes, such as slab dehydration, fluid transport, partial melting, melt extraction and crustal growth at continental margin [Zhu et al., 2013]. Details on the numerical approach and material properties used in our numerical experiments are available as Supplementary Material.

In all our experiments, the model domain measures $1500 \times 680 \times 656 \mathrm{~km}$ in the $x, y$ and $z$ directions, respectively, resolved by $437 \times 277 \times 149$ grid nodes giving a resolution of $3.4 \times$ $2.5 \times 4.4 \mathrm{~km}$ (Fig. 3a). Around 130 million additional randomly distributed markers are used for advecting the material properties and computing water release, transport and consumption as well as partial melting and melt extraction. The initial setup is designed with an overriding continental lithosphere and a subducting oceanic lithosphere including a small continent (i.e. $500 \times 328 \mathrm{~km}$ in $x$ and $z$ directions, respectively), which represent the Eurasian plate and the converging Mesogean and Arabian lithospheres, respectively (Figs. 1c and 3a). A $10 \mathrm{~km}$ thick trench-parallel weak zone is prescribed at the interface between the overriding and subducting lithospheres in order to initiate subduction. In our reference model, the overriding continental lithosphere is composed by $30 \mathrm{~km}$ and $20 \mathrm{~km}$ thick upper and lower crust, respectively, while the subducting continental crust is composed of $20 \mathrm{~km}$ and $10 \mathrm{~km}$ thick upper and lower crust, respectively (Figs. 3a and 3b). The initial thermal structure of the continents is laterally uniform and varies for each experiment (see Section 3.2). In the reference model, this is a linear vertical gradient with $0{ }^{\circ} \mathrm{C}$ at the surface and $1300{ }^{\circ} \mathrm{C}$ at $89 \mathrm{~km}$ and $98 \mathrm{~km}$ depth for the overriding and subducting continental lithospheres, respectively. The oceanic lithosphere incorporates a $3 \mathrm{~km}$ thick hydrated basaltic crust and a $5 \mathrm{~km}$ thick gabbroic crust and its thermal structure, also different for each experiment, is defined using a half-space cooling age (of $60 \mathrm{Ma}$ for the reference model) [Turcotte and Schubert, 2002]. These lithospheres overlay 
an asthenospheric mantle characterized by an initial adiabatic temperature gradient of $\sim 0.5^{\circ} \mathrm{C}$ $\mathrm{km}^{-1}$.

Velocity boundary conditions are free slip at both back and front boundaries $(z=0$ and $z=$ $656 \mathrm{~km}$ ). Material influx is imposed through the right and left boundaries ( $x=0$ and $x=1500$ $\mathrm{km})$. Velocities across these boundaries are null except for the first $250 \mathrm{~km}$ depth of the right boundary where a $\sim 1.9 \mathrm{~cm} \mathrm{yr}^{-1}$ influx is applied (Fig. 3a), scaled on the African plate absolute motion estimated between 1.2 and $2.5 \mathrm{~cm} \mathrm{yr}^{-1}$ since the Oligocene [Jolivet and Faccenna, 2000]. The mass conservation is then ensured by material outflux through the upper and lower permeable boundaries ( $y=0$ and $y=680 \mathrm{~km}$ ). The top surface of the lithosphere is calculated dynamically as an internal free surface by using an initial $12-15 \mathrm{~km}$ thick low-viscosity layer simulating either air (for $y<12 \mathrm{~km}$ ) or sea water. The large viscosity contrast caused by this low-viscosity layer minimizes shear stresses at the top of the lithospheres that effectively approximates a free surface [Schmeling et al., 2008].

\subsection{Parametric study on lithospheric geothermal gradient and rheological layering}

To assess the role of subduction dynamics on magma genesis and transport, we explore a wide range of rheological profiles of interacting continental and oceanic plates by changing their thermal gradients (Table S2). In addition, since there is no consensus on the rheological structure of the lithosphere, especially in the eastern Mediterranean region whose geodynamical history is long and complex, different rheological layering have been tested for the continental lithospheres by defining either one or two crustal layers characterized by distinct non-Newtonian rheologies (Figs. 3a and b). We thereby control the overall rheological contrast and therefore the degree of plate coupling between the interacting lithospheres in our experiments [Gerya and Meilick, 2011] leading to reproduce different regimes of subduction with either advancing or retreating trench. Changing the lithospheric 
thermal gradients also modifies the degree of partial melting of the lithosphere, allowing us to investigate the weakening effect of magmas on lithospheric deformation. In the following, we use acronyms like 2c89-60 for model with two-layer continental crust, an overriding lithosphere $1300{ }^{\circ} \mathrm{C}$ isotherm at $89 \mathrm{~km}$ depth and 60-Myr old oceanic lithosphere (Fig. 3a).

\section{Results}

In this section, we outline the main numerical results through a series of figures obtained from selected experiments (Table S2) focusing on the overall evolution of these models, on the resulting asthenospheric and lithospheric flow pattern and on the genesis and evolution of partially molten rocks from the mantle to the crust. Figs. 4 and 5 illustrate the evolution of models 2c89-60 and 1c113-70, characterized by two- and one-layer continental crust, respectively. Fig. 6 shows the temporal variations of the velocity of trench migration from selected experiments and from kinematic reconstructions of the eastern Mediterranean region [Menant et al., 2016]. Fig. 7 highlights the mantle and crustal flow pattern and the strain rate distribution in the overriding lithosphere from selected models. Finally, Figs. 8 and 9 illustrate the temporal distribution of partially molten rocks from models $2 c 89-60$ and $1 c 113-70$. Additional results are also described in this section, although related figures are available as Supplementary Material.

\subsection{Succession of events: oceanic and continental subduction followed by slab tearing}

In our reference model 2c89-60 (Fig. 4; Videos S1 and S2), subduction initiates through progressive bending and roll-back of the oceanic slab, associated with a homogeneous stretching of the overriding continental lithosphere (Fig. 4a). Subsequent continental subduction then induces along-trench buoyancy variations resulting in progressive curvature of the trench (Fig. 4b). When the continental slab reaches $\sim 150 \mathrm{~km}$ depth, trench-parallel 
tearing occurs at the transition between the more buoyant continental lithosphere and the oceanic lithosphere (Fig. 4b). The slab tear then propagates along this compositional boundary inducing trench-perpendicular tearing (Fig. 4c). Once decoupled from the oceanic lithosphere, the torn continent bends up and collides into the overriding plate while the still active oceanic subduction zone continues to retreat associated with slab flattening. This succession of events is robust through all experiments with two-layer continental crust (model 2c84-100 with higher lithospheric thermal gradient; Fig. S1), except when the lithospheric thermal gradient is low, which leads to overall compression in the overriding lithosphere (model 2c98-100; Fig. S2a). This transient evolution is also consistent in models with onelayer continental crust (model 1c113-70; Fig. 5; Videos S3 and S4) with the exception of a higher stretching of the subducting continental lithosphere also associated with crustal decoupling, which thus delays slab tearing (Figs. 5b and c). It is noteworthy that the apparent lack of lithospheric mantle below the overriding stretched continental crust (model 1c113-70; Fig. 5) does not imply that the crust lies directly on the asthenosphere. Depending on the evolution of the thermo-mechanical properties of the peridotite, the lithosphere-asthenosphere boundary is therefore more accurately defined in our experiments by considering the $1200{ }^{\circ} \mathrm{C}$ isotherm (Fig. 3b).

In all numerical experiments, laterally varying subduction dynamics exerts a major control on the surface kinematics. Coeval subduction of oceanic and continental lithospheres results in an along-trench variation of the rate of trench retreat evolving in the reference model $2 c 89$ 60 from $\sim 2 \mathrm{~cm} \mathrm{yr}^{-1}$ to $3-6 \mathrm{~cm} \mathrm{yr}^{-1}$ above the continental and oceanic slab, respectively (Fig. 6a). Once slab tearing has occurred, trench retreat accelerates above the continuing oceanic subduction zone reaching up to $\sim 6 \mathrm{~cm} \mathrm{yr}^{-1}$ in this model. Models with higher lithospheric thermal gradient show a sensibly faster trench retreat (model $2 c 84-100 ; \sim 9 \mathrm{~cm} \mathrm{yr}^{-1}$ ), while those with a lower lithospheric thermal gradient are characterized by a slowly advancing 
oceanic trench (model 2c98-100; 0.5-2 $\mathrm{cm} \mathrm{yr}^{-1}$; Fig. 6b). Finally, models with one-layer continental crust (model 1c113-70) also show faster trench retreat than the reference model despite a lower lithospheric thermal gradient (reaching up to $\sim 7 \mathrm{~cm} \mathrm{yr}^{-1}$ above the fast retreating oceanic slab; Fig. 6c). The magnitude of these trench velocities is broadly similar to the rate of trench retreat for the Hellenic subduction system, estimated between 0.5 and 3 $\mathrm{cm} \mathrm{yr}^{-1}$ during the late Cenozoic (see solid line in Fig. 6d) [Menant et al., 2016].

\subsection{Asthenospheric vs. lithospheric flow pattern}

Except for model 2c98-100 characterized by major compressional tectonics (Fig. S2), all performed numerical experiments show an initial dominant poloidal asthenospheric flow, initiated at the slab tip and upwelling into the mantle wedge (Fig. 7a). When slab tearing occurs, the asthenospheric flow changes to a poloidal flow coming through the newly formed slab windows then evolving in a toroidal flow, which finally reaches the mantle wedge (Fig. 7b). Meanwhile, extrusion of the overriding lithosphere towards the oceanic subduction occurs (Figs. 4c and 5c). Extrusion tectonics in models with two-layer continental crust takes place in a restricted zone above the trench-perpendicular slab tear, where the deformation is localized along a strike-slip fault zone (Fig. 7c). Lithospheric and asthenospheric flows in the extensional back-arc domain are then sub-parallel and controlled by the slab roll-back (Fig. 7d). However, the horizontal component of flow velocity at the lithosphere-asthenosphere boundary is subject to an abrupt decrease (see velocity profile in inset of Fig. 7c). Conversely, models with one-layer continental crust are characterized by more pronounced strike-slip faulting during upper plate extrusion reaching a wide extensional region above the fast retreating oceanic slab (Fig. 7e). In addition, the comparatively weaker continental lithosphere in this extensional domain allows for more efficient transmission of the asthenospheric flow to the overriding lithosphere, as shown by a progressive decrease of the horizontal component 
of flow velocity from the asthenosphere to the upper part of the continental crust (see velocity profile in inset of Fig. 7e).

\subsection{Genesis and transport of partially molten rocks}

In our reference model 2c89-60 (Fig. 8), the first stage of oceanic subduction is associated with (1) partial melting of the lower continental crust of the overriding lithosphere (Figs. 8a and c) and (2) water release from the hydrated subducting oceanic crust at $\sim 70 \mathrm{~km}$ depth (Fig. 8d). Subsequent hydration of the mantle wedge contributes to its partial melting resulting in a wave-like plume geometry of partially molten mantle (according to the magmatic plume description of Zhu et al. [2009]) that starts to ascend at $\sim 150 \mathrm{~km}$ depth (Figs. 4a and 8d). While the oceanic slab retreats, partially molten crust and mantle are stored at the base of the overriding crust, being passively transferred from the arc to the back-arc domain through time (see vertical cross-sections in Fig. 8). The up-bending of the subducting continental lithosphere resulting from slab tearing is accompanied by fast rising and storage of partially molten mantle and continental crust as well as of dry asthenosphere below the active collision zone (Figs. 8e and h). A significant amount of partially molten sediments is then added to the stacked material, which is laterally transferred through the collision zone into the back-arc domain and exhumed through the stretching crust up to the surface (Figs. 8i and k). Lateral migration of partially molten mantle at the base of the stretched crust above the ongoing subduction zone also takes place (Fig. 8e) and is progressively replaced by dry asthenosphere (Fig. 8i).

In model 2c98-100 displaying slow subduction associated with a compressional regime (Figs. S2b and c), the magmatic activity is restricted to small amounts of partially molten continental crust and sediments slowly ascending within the thickening overriding lithosphere. In model 2c84-100 characterized by two-layer continental crust and fast slab roll- 
back (Fig. S1), the hydrated and partially molten rocks evolution is faster, similar to the reference model $2 c 89-60$, except that the wave-like plume of partially molten mantle in the mantle wedge develops later (Fig. S3). Finally, the magmatic evolution of model 1c113-70 with one-layer continental crust shows a number of differences. (1) A major partial melting event occurs at the base of the overriding crust (Fig. 5). The partially molten material is then progressively exhumed through the stretched crust forming a high temperature dome-like structure (Figs. 9a, c and j). (2) The ascent of partially molten mantle in the mantle wedge starts deeper, from $\sim 300 \mathrm{~km}$ depth (Fig. 5a) and occurs as a wave-like plume (Fig. 5b), except around the torn continental slab where it ascends as regularly-spaced finger-like plumes (Fig. 5c). (3) The long residence time of continental slab at depth before tearing results in increasing partial melting of the crust and subsequently finger-like upwelling of melts (Fig. 9g).

\section{Discussion}

We discuss below the relationships between magmatism, mantle flow and lithospheric deformation assuming that partially molten rocks mimic magmatic sources from which magmas with specific composition are potentially extracted. Finally, we compare our results to observations from the eastern Mediterranean region.

\subsection{Ascent of partially molten mantle}

During the initial subduction of the oceanic lithosphere, slab dehydration and subsequent hydrated partial melting result in the accumulation of mantle-derived melts within the mantle wedge [Grove et al., 2006]. According to our models, partially molten mantle with lower viscosity and density rises up as plumes (Figs. 8b and 9b). This ascent is controlled by the competition between the buoyancy of partially molten rocks and the subduction drag 
(depending on viscosity and slab dip). The predominance of the buoyancy force results in the development of Rayleigh-Taylor instabilities at the interface between hydrated/partially molten mantle and dry mantle, initiating plume rising. Zhu et al. [2013] suggest that plate convergence rate affects the depth of the plume growth with faster plate convergence (i.e. $\sim 6.5 \mathrm{~cm} \mathrm{yr}^{-1}$ ) carrying more efficiently the hydrated oceanic crust down the subduction zone than slower plate convergence (i.e. $\sim 2 \mathrm{~cm} \mathrm{yr}^{-1}$ ). We can add upon this evidence that the asthenospheric flow related to slab roll-back and tearing is another crucial process affecting the initiation and trajectories of partially molten rock upwelling through the mantle wedge. Indeed, as soon as subduction and subsequent partial melting of the hydrated mantle start, a sub-horizontal asthenospheric flow develops in the mantle wedge as a result of the dominant poloidal flow component initiated at the slab tip $\left(\sim 5 \mathrm{~cm} \mathrm{yr}^{-1}\right.$; model $2 c 89-60$; Figs. $8 \mathrm{~d}$ and 10a). This sub-horizontal asthenospheric flow, particularly fast for high rate of slab roll-back, is then deflected downward close to the slab-mantle interface $\left(\sim 10 \mathrm{~cm} \mathrm{yr}^{-1}\right.$; model $1 \mathrm{c} 113-70$, Figs. 9d and 10b) resulting in an asthenospheric return flow that tends to delay the growth of the plumes (initiated $\sim 300 \mathrm{~km}$ depth in model 1c113-70, Fig. 5a). Conversely, slab roll-back and tearing promotes an asthenospheric upwelling which drags upward partially molten rocks in the mantle wedge (Figs. 8k and 9k). In our experiments, this magmatic source mainly ascends as wave-like plumes (Figs. $4 \mathrm{~b}$ and $5 \mathrm{~b}$ ) but also as finger-like plumes, especially close to the torn continental slab (model 1c113-70, Figs. 5b and c). Zhu et al. [2009] argued that the main controlling factor on the geometry of these plumes is the viscosity variation of the partially molten material. In this study, the constant viscosity of $10^{19} \mathrm{~Pa}$ s for these partially molten phases (constrained by imposing a lower cut-off value for viscosities in our experiments, see Supplementary Material) suggests that other factors also control the plume structure in the mantle wedge. We find here that finger-like plumes initiate above a steep and slow sinking slab associated with slow asthenospheric return flow (Fig. 9h; $\sim 1.6 \mathrm{~cm} \mathrm{yr}^{-1}$ ), 
when the continental slab buoyancy force counterbalances the slab pull force. The reduced stress imposed by this slow asthenospheric flow then promotes the development of alongtrench Rayleigh-Taylor instabilities at the slab-mantle interface enabling the growth of fingerlike plumes. Conversely, in the case of fast retreating slab (Figs. 8j and 9j), related faster asthenospheric flow (i.e. $\sim 6 \mathrm{~cm} \mathrm{yr}^{-1}$ ) avoids the initiation of these along-trench RayleighTaylor instabilities resulting in the ascent of partially molten rocks as a wave-like plume.

\subsection{Magmatic evolution in the lower crust and mantle flow}

Besides controlling the ascending trajectories of magmatic sources through the mantle wedge, the dominant toroidal asthenospheric flow related to slab tearing (Figs. 10c and d) drives the trench-parallel migration of magmas and their emplacement at the base of the overriding continental crust. Here, both partially molten mantle and crust are stored during the first stage of subduction (Figs. 8 and 9) with a predominance of crustal-derived magmas, especially in model $1 c 113-70$ where the prescribed one-layer continental crust is less refractory than the two-layer continental crust defined in model $2 c 89-60$. When slab tearing occurs, large amount of both partially molten crust and mantle are stored at the base of the overriding crust (Figs. 8e and 9e). Subsequent toroidal asthenospheric flow due to protracted roll-back of the oceanic slab then drags these magmatic sources from the collision zone to the back-arc domain, above the retreating subduction (Figs. 10c and d). In addition, we found a lateral increase of mantle-derived relative to crust-derived melts in the back-arc domain (Fig. 5e) and a final upwelling of hot and dry asthenosphere potentially resulting in the adiabatic melting of depleted mantle, which is not considered in the model (Figs. 8i and 9i). Implementation of this magmatic process should be therefore a major improvement for future works in order to discuss the control of asthenospheric upwelling on the genesis of magmas with alkaline composition in the back-arc domain. 
No significant contribution from partial melting of the oceanic crust was recognized in our experiments, in turn suggesting that most magmas within the mantle wedge are generated from hydrated mantle, even in warm subduction zones [Bouilhol et al., 2015]. In the MASH zone, mantle- and crustal-derived magmas may mix and therefore change composition, as if they undergo fractionation and crustal assimilation processes [Hildreth and Moorbath, 1988]. Sedimentary material likely contributes to the maturation of these magmas in the MASH zone, especially across continental subduction zone where the strong coupling of the continental lithospheres enhances the basal erosion of the upper plate along the subduction interface and therefore the burial of detrital continental crust (Figs. 8i and k).

\subsection{Magmatism and lithospheric deformation}

Low-viscosity partially molten rocks stored in the overriding lithosphere allow for decreasing the bulk strength of the upper plate [Watts and Burov, 2003] thus favoring partial decoupling between the continental crust and the underlying lithospheric mantle (Figs. 9b and f). This melt-induced lithospheric weakening also enhances the decoupling at the subduction interface, which in turn increases the rate of slab roll-back, thereby affecting lateral extrusion and stretching of the upper plate (Fig. 7; comparison between slow evolving models $2 c 89-60$ and $2 c 98-100$ and fast evolving models $1 c 113-70$ and $2 c 84-100)$.

In our experiments, low-viscosity partially molten rocks exhumed through the overriding crust also provide a strong rheological contrast with the surrounding high-viscosity rocks (Figs. 8b and 9b) affecting the distribution of crustal deformation. Strike-slip faulting and back-arc-related intense lithospheric stretching thus localize in the weaker parts of the crust accommodating the lateral extrusion of continental block and fast slab roll-back, respectively (model 2c89-60; Fig. 7c). Moreover, in accordance with previous studies [Gerya and Meilick, 2011; Capitanio, 2014], our experiments show that a large amount of partial melting of the 
overriding crust decreases the bulk lithospheric strength and favors the propagation of the strike-slip fault zone and the opening of a wider back-arc basin (model 1c113-70; Fig. 7e).

The driving forces of plate tectonics across subduction-collision environment have been largely discussed in term of crustal and mantle contributions [e.g. Royden, 1996; Jolivet et al., 2009; Faccenna and Becker, 2010]. Recently, Sternai et al. [2014] proposed that extrusion tectonics may be jointly driven by continental collision, slab roll-back and associated mantle flow, the latter being particularly effective across hot and thin lithospheres. Indeed, the viscosity contrast between such lithosphere and the underlying asthenosphere is low (i.e. $~ 10$ Pa s; see Fig. 4 of Sternai et al. [2014]) promoting lithosphere/asthenosphere coupling. Our results further suggest that the decrease of the bulk lithospheric strength by the magmatic input results in a lower viscosity contrast along the lithosphere-asthenosphere boundary (i.e. less than $10^{2} \mathrm{~Pa} \mathrm{~s}$; inset of Fig. 7e) therefore favoring the lithosphere/asthenosphere coupling. This is a crucial mechanism for transmission of the velocities from the flowing mantle to the crust (inset of Fig. 7e). In addition, sub-parallel crustal and asthenospheric velocity fields in the back-arc domain where the upper lithosphere is thin, hot and therefore weak (Figs. 7d and f), suggest that the strain is, at least to some extent, controlled by the underlying asthenospheric flow in agreement with field observations [Jolivet et al., 2009].

These results emphasize the role of mantle and crustal magmas on upper plate deformation and lithosphere/asthenosphere coupling in subduction zone by decreasing the bulk lithospheric strength. Applied to the strong downgoing lithosphere, such a melt-induced lithospheric weakening could be considered as an efficient and required mechanism for slab bending. Absence of slab partial melting in our experiments does not confirm this hypothesis but fluid-induced weakening [Gerya and Meilick, 2011] related to slab hydration could be an alternative explanation to reduce the slab strength. Normal faulting occurring in the upper, 
brittle part of the slab would then have promoted this weakening effect by enhancing deep slab hydration [Faccenda et al., 2009].

\subsection{Implications for the eastern Mediterranean region}

The late Cenozoic geodynamics of the eastern Mediterranean region, in particular coeval retreat of the Hellenic subduction zone and collision across the Arabia-Eurasia margin (Fig. 1c) [Jolivet and Faccenna, 2000], are consistently reproduced by our numerical experiments (Figs. 4, 5 and S1). At depth, slab tearing occurs in these models along the ocean-continent transition, which is consistent with seismic tomographic models proposing the existence of two slab tears beneath western and eastern Anatolia (Fig. 2b) [de Boorder et al., 1998; Wortel and Spakman, 2000; Li et al., 2008]. In addition, the toroidal asthenospheric flow associated with slab roll-back and tearing in our experiments (Fig. 7) is consistent with instantaneous 3D velocity field calculations for the flowing mantle [Faccenna and Becker, 2010] and other self-consistent 3D numerical studies applied to the eastern Mediterranean region [Li et al., 2013; Capitanio, 2014; Duretz et al., 2014; Sternai et al., 2014]. No clear correlation, however, can be done between this toroidal flow and the SKS fast splitting directions (Fig. 2b) [Paul et al., 2014] suggesting a more complex relationship between the SKS orientations and the asthenospheric flow pattern in this region (see discussion of $L e$ Pichon and Kreemer [2010]).

According to our results, slab tearing is correlated with the extrusion of crustal block from the collisional domain toward the retreating subduction zone resulting in an overall counterclockwise crustal velocity pattern (Figs. 7c and e), similar to the present-day crustal kinematics across the study region deduced from GPS measurements (Fig. 2a) [Reilinger et al., 2006; Le Pichon and Kreemer, 2010]. The magnitude of these crustal velocities is also

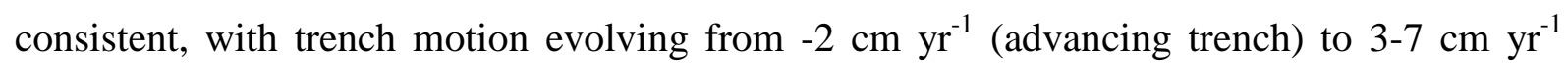


(retreating trench) in models $2 c 89-60$ and $1 c 113-70$ and from 0.5 to $3 \mathrm{~cm} \mathrm{yr}^{-1}$ for the Hellenic trench (Fig. 6) [Menant et al., 2016]. Acceleration of trench retreat, combined with an advancing collisional front in our experiments as well as in the natural case can be related to slab tears, which would confirm the middle-late Miocene age for slab tearing in the eastern Mediterranean region [Faccenna et al., 2006; Dilek and Altunkaynak, 2009; Jolivet et al., 2015]. Small differences in these velocities may be, to some extent, due to the imposed free slip conditions at the front and back boundaries $(z=0$ and $z=656 \mathrm{~km})$ laterally constraining the crustal and mantle flow. Additional numerical experiments accounting for open boundaries as well as the neighboring plates would then allow for more realistic boundary conditions and therefore more accurate crustal velocities [Yamato et al., 2009].

Mimicking the NAF accommodating the lateral extrusion of Anatolia since 12 Ma, localized strike-slip fault zone is fairly well reproduced in models characterized by a weak overriding lithosphere (model 1c113-70; Fig. 7e). Conversely, the propagation of this localized strike-slip deformation is reduced within a strong lithosphere (model 2c89-60; Fig. 7c). A weak overriding lithosphere also allows for opening of a wide back-arc basin (model 1c113-70; Fig. 7e) characterized by a $\sim 50 \mathrm{~km}$ thick lithosphere (inset of Fig. 7e), which is consistent with the present-day 40-50 km thick Aegean lithosphere [Endrun et al., 2008]. In addition, the exhumation in the back-arc domain of partially molten rocks as dome-like structures (model 1c113-70, Fig. 8c) mimic high-temperature MCCs with migmatitic core, recognized in the Rhodope and Menderes massifs as well as in the Cyclades archipelago [Lister et al., 1984; Bozkurt and Oberhänsli, 2001; Vanderhaeghe, 2004; Brun and Sokoutis, 2007; Jolivet et al., 2013]. These similarities suggest that the late Cenozoic deformation pattern in the eastern Mediterranean region is controlled by the melt-induced weakening of the lithosphere, especially in the Aegean back-arc domain where the emplacement of 
magmatic bodies with a major crustal source component confirms an intense partial melting of the lower crust [Pe-Piper and Piper, 2006; Ersoy and Palmer, 2013].

Space and time distribution of these magmatic products is also characterized by a firstorder southward migration driven by slab roll-back (see orange arrow, Fig. 1a) [Pe-Piper and Piper, 2006; Dilek and Altunkaynak, 2009; Ersoy and Palmer, 2013], which is fairly well reproduced in our models (Figs. 8 and 9). During the Miocene, this magmatic trend is modulated by a second-order southwestward migration from the Menderes massif to the Cyclades (see yellow arrow, Fig. 1a), which is also faithfully reproduced in our model with an along-trench migration of partially molten rocks at the base of the crust controlled by the toroidal asthenospheric flow related to slab tearing (Figs. 10c and d). This along-trench migration of magmatic activity in the Aegean domain is accompanied by an increase of the mantle-sourced magmas [Jolivet et al., 2015], a feature that some experiments fail to reproduce (model 1c113-70; Fig. 9i), probably due to the insufficient numerical resolution that buffered the mantle signature in the intensively partially molten continental crust. Conversely, this trend is recognized in model $2 c 89-60$ considering two-layer continental crust (Fig. 8e), where increasing mantle-sourced magmatic component at the base of the overriding crust mimics observations from the Miocene intrusions across the Cyclades [Jolivet et al., 2015].

Eastern Anatolia is further characterized by a wide calc-alkaline to alkaline volcanic province of late Miocene to Quaternary age (Fig. 1c) [Keskin, 2003]. In our experiments, partially molten mantle and crust accumulate at the base of the collision zone due to the subcollisional slab detachment potentially resulting in such a wide magmatic activity (Figs. 8e and 9e). Later alkaline volcanism emplaced in the eastern Mediterranean region resulting from the adiabatic partial melting of depleted asthenosphere [Keskin, 2003; Ersoy and 
Palmer, 2013] which can be related to the asthenospheric upwelling associated with slab tearing and intense lithospheric stretching reproduced in our experiments (Figs. 8i and 9i).

Our results clearly emphasize the role of slab roll-back and tearing and related asthenospheric flow on the late Cenozoic magmatic and tectonic evolution of the eastern Mediterranean region. Of course, these 3D models cannot fully assess the natural complexity of the eastern Mediterranean subduction zone, characterized by successive oceanic and continental subduction events and, possibly, several slab tearing processes [Stampfli and Borel, 2002; Menant et al., 2016]. However, consistency between our experiments and the natural case in terms of crustal kinematics, deformation and magmatic evolution suggests that we reproduce the first-order crustal and mantle dynamics of the eastern Mediterranean subduction zone during the late Cenozoic.

\section{Conclusions}

Using a 3D high-resolution coupled petrological and thermo-mechanical model integrating experimentally calibrated non-Newtonian crustal and mantle rheologies, we are able to reproduce the first-order geodynamic evolution of a coeval oceanic and continental subduction zone characterized by slab roll-back and tearing. Integrating slab dehydration, fluid transport and partial melting processes, our experiments demonstrated (1) the control of 3D subduction dynamics and related asthenospheric flow on space and time evolution of magmas from the upper mantle to the overriding crust and (2) the significant role of meltinduced rheological weakening on lithospheric deformation. In detail, we reach the following conclusions.

- Slab dynamics and associated mantle flow affect magma genesis and transport within the hydrated mantle wedge. A typical asthenospheric return flow in the mantle wedge tends to delay the ascent of partially molten rocks. Conversely, asthenospheric upwelling associated 
with slab roll-back and tearing allows for a fast ascent of the magmatic sources as plumes with variable morphologies. A slow sinking slab thus promotes the development of alongtrench Rayleigh-Taylor instabilities at the slab-mantle interface favoring finger-like plumes, while fast evolving subduction zone and associated asthenospheric flow facilitate the ascent of large amount of partially molten material as wave-like plumes.

- During their emplacement, both mantle- and crust-derived magmas contribute to the reduction of the bulk strength of the overriding lithosphere thereby affecting the deformation pattern. The ascent of large amounts of partially molten material within the stretched crust localizes deformation along dome-like structures. The crustal deformation is then characterized by strike-slip faulting and stretching that accommodate the lateral extrusion of crustal block and slab roll-back, respectively. This melt-induced weakening of the crust also promotes the lithosphere/asthenosphere coupling and the transmission of the velocities from the flowing asthenosphere to the crust, supporting the hypothesis that the mantle flow may drag the crust thereby affecting surface deformation.

- The kinematic, strain and magmatic evolution of the eastern Mediterranean region deduced from geological and geophysical constraints are reasonably well reproduced by our experiments suggesting a major control of subduction dynamics and related asthenospheric flow on the magmatic evolution. As such, we propose that roll-back and tearing of the eastern Mediterranean slab may have controlled, respectively, the southward and southwestward migration of magmatic centers since the late Cenozoic.

\section{Acknowledgments}

This work was funded by the French Geological Survey (BRGM), the Région Centre, the ERC RHEOLITH project (ERC Advanced Grant $n^{\circ}$ 290864), the Labex VOLTAIRE (ANR10-LABX-100-01) and the Institut Universitaire de France. We are thankful to Eloise Bessière 
542 for her contribution in figures design. The paper benefited from relevant revision by Fabio A.

543 Capitanio and one anonymous reviewer. 


\section{References}

Arculus, R. J. (1994), Aspects of magma genesis in arcs, Lithos, 33(1-3), 189-208, doi:10.1016/00244937(94)90060-4.

Bouilhol, P., V. Magni, J. van Hunen, and L. Kaislaniemi (2015), A numerical approach to melting in warm subduction zones, Earth Planet. Sci. Lett., 411, 37-44, doi:10.1016/j.eps1.2014.11.043.

Bozkurt, E., and R. Oberhänsli (2001), Menderes Massif (Western Turkey): structural, metamorphic and magmatic evolution - a synthesis, Int. J. Earth Sci., 89(4), 679-708, doi:10.1007/s005310000173.

Brun, J.-P., and D. Sokoutis (2007), Kinematics of the Southern Rhodope Core Complex (North Greece), Int. J. Earth Sci., 96(6), 1079-1099, doi:10.1007/s00531-007-0174-2.

Capitanio, F. A. (2014), The dynamics of extrusion tectonics: Insights from numerical modeling, Tectonics, 33(12), 2361-2381, doi:10.1002/2014TC003688.

de Boorder, H., W. Spakman, S. H. White, and M. J. R. Wortel (1998), Late Cenozoic mineralization, orogenic collapse and slab detachment in the European Alpine Belt, Earth Planet. Sci. Lett., 164(3-4), 569-575, doi:10.1016/S0012-821X(98)00247-7.

Dilek, Y., and S. Altunkaynak (2009), Geochemical and temporal evolution of Cenozoic magmatism in western Turkey: mantle response to collision, slab break-off, and lithospheric tearing in an orogenic belt, Spec. Publ. - Geol. Soc. London, 311(1), 213-233, doi:10.1144/SP311.8.

Duretz, T., T. V. Gerya, and W. Spakman (2014), Slab detachment in laterally varying subduction zones: 3-D numerical modeling, Geophys. Res. Lett., 41(6), 1951-1956, doi:10.1002/2014GL059472.

Endrun, B., T. Meier, S. Lebedev, M. Bohnhoff, G. Stavrakakis, and H.-P. Harjes (2008), $S$ velocity structure and radial anisotropy in the Aegean region from surface wave dispersion, Geophys. $J$. Int., 174, 593-616, doi:10.1111/j.1365-246X.2008.03802.x.

Ersoy, E. Y., and M. R. Palmer (2013), Eocene-Quaternary magmatic activity in the Aegean: Implications for mantle metasomatism and magma genesis in an evolving orogeny, Lithos, doi:10.1016/j.lithos.2013.06.007.

Faccenda, M., T. V. Gerya, and L. Burlini (2009), Deep slab hydration induced by bending-related variations in tectonic pressure, Nat. Geosci., 2(11), 790-793, doi:10.1038/ngeo656.

Faccenna, C., O. Bellier, J. Martinod, C. Piromallo, and V. Regard (2006), Slab detachment beneath eastern Anatolia: A possible cause for the formation of the North Anatolian fault, Earth Planet. Sci. Lett., 242(1-2), 85-97, doi:10.1016/j.epsl.2005.11.046.

Faccenna, C., and T. W. Becker (2010), Shaping mobile belts by small-scale convection, Nature, 465(7298), 602-605, doi:10.1038/nature09064. 
Gerya, T. V., and D. A. Yuen (2007), Robust characteristics method for modelling multiphase viscoelasto-plastic thermo-mechanical problems, Phys. Earth Planet. Inter., 163(1-4), 83-105, doi:10.1016/j.pepi.2007.04.015.

Gerya, T. V., and F. I. Meilick (2011), Geodynamic regimes of subduction under an active margin: effects of rheological weakening by fluids and melts, J. Metamorph. Geol., 29(1), 7-31, doi:10.1111/j.1525-1314.2010.00904.x.

Hawkesworth, C. J. (1997), U-Th Isotopes in Arc Magmas: Implications for Element Transfer from the Subducted Crust, Science, 276(5312), 551-555, doi:10.1126/science.276.5312.551.

Hildreth, W., and S. Moorbath (1988), Crustal contributions to arc magmatism in the Andes of Central Chile, Contrib. Mineral. Petrol., 98(4), 455-489, doi:10.1007/BF00372365.

Huw Davies, J., and F. von Blanckenburg (1995), Slab breakoff: A model of lithosphere detachment and its test in the magmatism and deformation of collisional orogens, Earth Planet. Sci. Lett., 129(1-4), 85-102, doi:10.1016/0012-821X(94)00237-S.

Jadamec, M. A., and M. I. Billen (2010), Reconciling surface plate motions with rapid threedimensional mantle flow around a slab edge, Nature, 465(7296), 338-341, doi:10.1038/nature09053.

Johnson, H. P., and M. J. Pruis (2003), Fluxes of fluid and heat from the oceanic crustal reservoir, Earth Planet. Sci. Lett., 216(4), 565-574, doi:10.1016/S0012-821X(03)00545-4.

Jolivet, L., and C. Faccenna (2000), Mediterranean extension and the Africa-Eurasia collision, Tectonics, 19(6), 1095-1106, doi:10.1029/2000TC900018.

Jolivet, L., C. Faccenna, and C. Piromallo (2009), From mantle to crust: Stretching the Mediterranean, Earth Planet. Sci. Lett., 285(1-2), 198-209, doi:10.1016/j.eps1.2009.06.017.

Jolivet, L. et al. (2013), Aegean tectonics: Strain localisation, slab tearing and trench retreat, Tectonophysics, 597-598, 1-33, doi:10.1016/j.tecto.2012.06.011.

Jolivet, L. et al. (2015), The geological signature of a slab tear below the Aegean, Tectonophysics, 659, 166-182, doi:10.1016/j.tecto.2015.08.004.

Katz, R. F., M. Spiegelman, and C. H. Langmuir (2003), A new parameterization of hydrous mantle melting, Geochem. Geophys. Geosyst., 4(9), n/a-n/a, doi:10.1029/2002GC000433.

Keskin, M. (2003), Magma generation by slab steepening and breakoff beneath a subduction-accretion complex: An alternative model for collision-related volcanism in Eastern Anatolia, Turkey, Geophys. Res. Lett., 30(24), doi:10.1029/2003GL018019.

Le Pichon, X., and C. Kreemer (2010), The Miocene-to-Present Kinematic Evolution of the Eastern Mediterranean and Middle East and Its Implications for Dynamics, Annu. Rev. Planet. Sci. 38(1), 323-351, doi:10.1146/annurev-earth-040809-152419. 
Li, C., R. D. van der Hilst, E. R. Engdahl, and S. Burdick (2008), A new global model for P wave speed variations in Earth's mantle, Geochem. Geophys. Geosyst., 9(5), doi:10.1029/2007GC001806.

Li, Z.-H., Z. Xu, T. Gerya, and J.-P. Burg (2013), Collision of continental corner from 3-D numerical modeling, Earth Planet. Sci. Lett., 380, 98-111, doi:10.1016/j.eps1.2013.08.034.

Lister, G. S., G. Banga, and A. Feenstra (1984), Metamorphic core complexes of Cordilleran type in the Cyclades, Aegean Sea, Greece, Geology, 12(4), 221, doi:10.1130/00917613(1984)12<221:MCCOCT>2.0.CO;2.

Magni, V., C. Faccenna, J. van Hunen, and F. Funiciello (2014), How collision triggers backarc extension: Insight into Mediterranean style of extension from 3-D numerical models, Geology, 42(6), 511-514, doi:10.1130/G35446.1.

Menant, A., L. Jolivet, and B. Vrielynck (2016), From crustal to mantle dynamics, insight from kinematic reconstructions and magmatic evolution of the eastern Mediterranean region since the late Cretaceous, Tectonophysics.

Nikolaeva, K., T. V. Gerya, and J. A. D. Connolly (2008), Numerical modelling of crustal growth in intraoceanic volcanic arcs, Phys. Earth Planet. Inter., 171(1-4), 336-356, doi:10.1016/j.pepi.2008.06.026.

Paul, A., H. Karabulut, A. K. Mutlu, and G. Salaün (2014), A comprehensive and densely sampled map of shear-wave azimuthal anisotropy in the Aegean-Anatolia region, Earth Planet. Sci. Lett., 389, 14-22, doi:10.1016/j.epsl.2013.12.019.

Pe-Piper, G., and D. J. W. Piper (2006), Unique features of the Cenozoic igneous rocks of Greece, Spec. Pap. - Geol. Soc. Am., 409, 259-282.

Ranalli, G. (1995), Rheology of the Earth, Chapman \& Hall., London, UK.

Reilinger, R. et al. (2006), GPS constraints on continental deformation in the Africa-Arabia-Eurasia continental collision zone and implications for the dynamics of plate interactions, J. Geophys. Res., 111(B5), doi:10.1029/2005JB004051.

Royden, L. (1996), Coupling and decoupling of crust and mantle in convergent orogens: Implications for strain partitioning in the crust, J. Geophys. Res., 101(B8), 17679, doi:10.1029/96JB00951.

Schmeling, H. et al. (2008), A benchmark comparison of spontaneous subduction models-Towards a free surface, Phys. Earth Planet. Inter., 171(1-4), 198-223, doi:10.1016/j.pepi.2008.06.028.

Şengör, A. M. C., O. Tüysüz, C. İmren, M. Sakınç, H. Eyidoğan, N. Görür, X. Le Pichon, and C. Rangin (2005), The North Anatolian Fault: A New Look, Annu. Rev. Earth Planet. Sci., 33(1), 37-112, doi:10.1146/annurev.earth.32.101802.120415.

Stampfli, G. M., and G. D. Borel (2002), A plate tectonic model for the Paleozoic and Mesozoic constrained by dynamic plate boundaries and restored synthetic oceanic isochrons, Earth Planet. Sci. Lett., 196(1-2), 17-33, doi:10.1016/S0012-821X(01)00588-X. 
Sternai, P., L. Jolivet, A. Menant, and T. Gerya (2014), Driving the upper plate surface deformation by slab rollback and mantle flow, Earth Planet. Sci. Lett., 405, 110-118, doi:10.1016/j.eps1.2014.08.023.

Turcotte, D. L., and G. Schubert (2002), Geodynamics, Cambridge University Press., Cambridge, UK.

Vanderhaeghe, O. (2004), Structural development of the Naxos migmatite dome, Spec. Pap. - Geol. Soc. Am., 380, 211-227.

Watts, A. B., and E. B. Burov (2003), Lithospheric strength and its relationship to the elastic and seismogenic layer thickness, Earth Planet. Sci. Lett., 213, 113-131, doi:10.1016/S0012821X(03)00289-9.

Wortel, M. J. R., and W. Spakman (2000), Subduction and Slab Detachment in the MediterraneanCarpathian Region, Science, 290(5498), 1910-1917, doi:10.1126/science.290.5498.1910.

Yamato, P., L. Husson, J. Braun, C. Loiselet, and C. Thieulot (2009), Influence of surrounding plates on 3D subduction dynamics, Geophysical Research Letters, 36(L07303), doi:10.1029/2008GL036942.

Zhu, G., T. V. Gerya, D. A. Yuen, S. Honda, T. Yoshida, and J. A. D. Connolly (2009), Threedimensional dynamics of hydrous thermal-chemical plumes in oceanic subduction zones, Geochem. Geophys. Geosyst., 10(11), doi:10.1029/2009GC002625.

Zhu, G., T. V. Gerya, P. J. Tackley, and E. Kissling (2013), Four-dimensional numerical modeling of crustal growth at active continental margins, Journal of Geophysical Research: Solid Earth, 118(9), 4682-4698, doi:10.1002/jgrb.50357. 

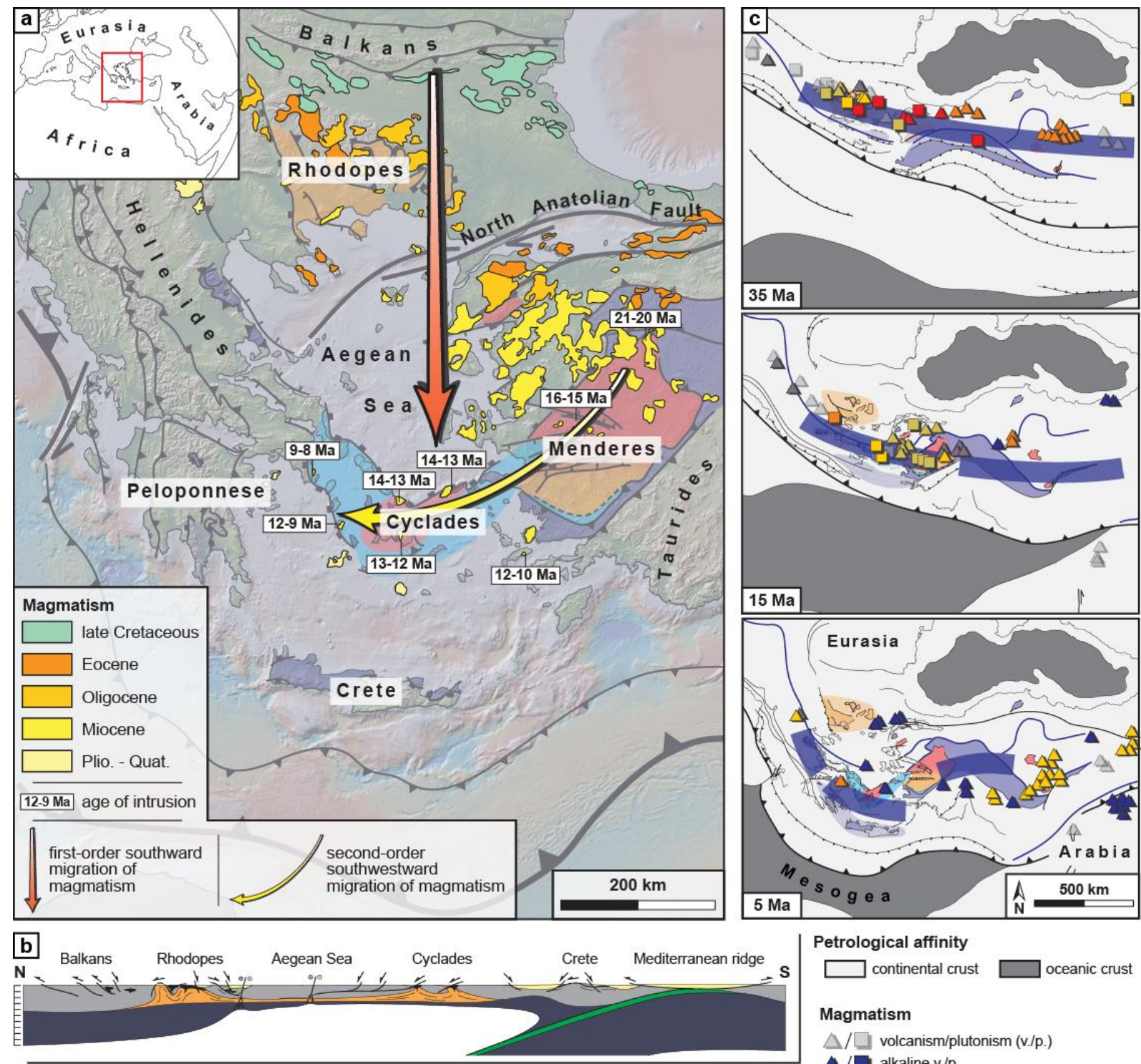

Main metamorphic complexes

Major tectonic structures

Subducted lithosphere

$\square$ buried/exhumed HP metamorphics

buried/exhumed partially

retrograded $\mathrm{HP}$ metamorphics

$\square$ buried/exhumed MT metamorphics

1 active thrust fault

active low-angle normal fault

$\sim$ active strike-slip fault

inactive fault

$\square$ buried/exhumed HT metamorphics

major oceanic suture

Petrological affinity

$\square$ continental crust

oceanic crust

Magmatism

$\Delta / \square$ volcanism/plutonism (v./p.)

Fig. 1: Late Cenozoic geodynamic evolution of the eastern Mediterranean region. (a) Tectonic map of the eastern Mediterranean region showing the spatial distribution of the magmatism since the late

671 Cretaceous. Red and yellow arrows show, respectively, the first-order southward migration of the 672 magmatism since the late Cretaceous and the second-order southwestward migration of the magmatism during the Miocene. (b) Present-day N-S cross-section across the Rhodope-Aegean region. (c) Paleotectonic maps of the eastern Mediterranean region at 35, 15 and 5 Ma showing the spatial distribution of contemporaneous magmatic occurrences. Modified from Menant et al. [2016]. 

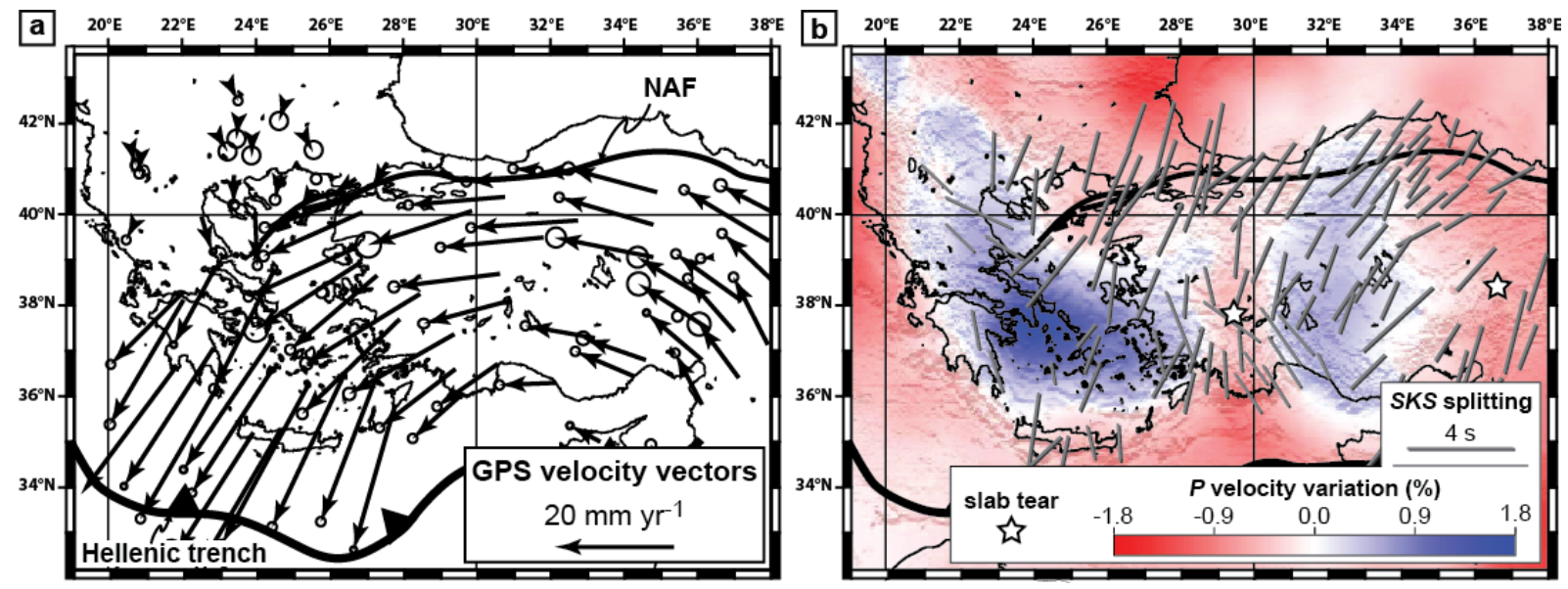

677 Fig. 2: Geophysical maps of the eastern Mediterranean region. (a) GPS velocities relative to stable

678 Eurasia with $1 \sigma$ confidence ellipses [Reilinger et al., 2006]. (b) Seismic tomographic model showing 679 the Vp anomalies at $\sim 150 \mathrm{~km}$ depth [Li et al., 2008]. Slab tears suspected in the region are highlighted 680 by white stars. Station-averaged SKS splitting data are also highlighted [Paul et al., 2014]. 


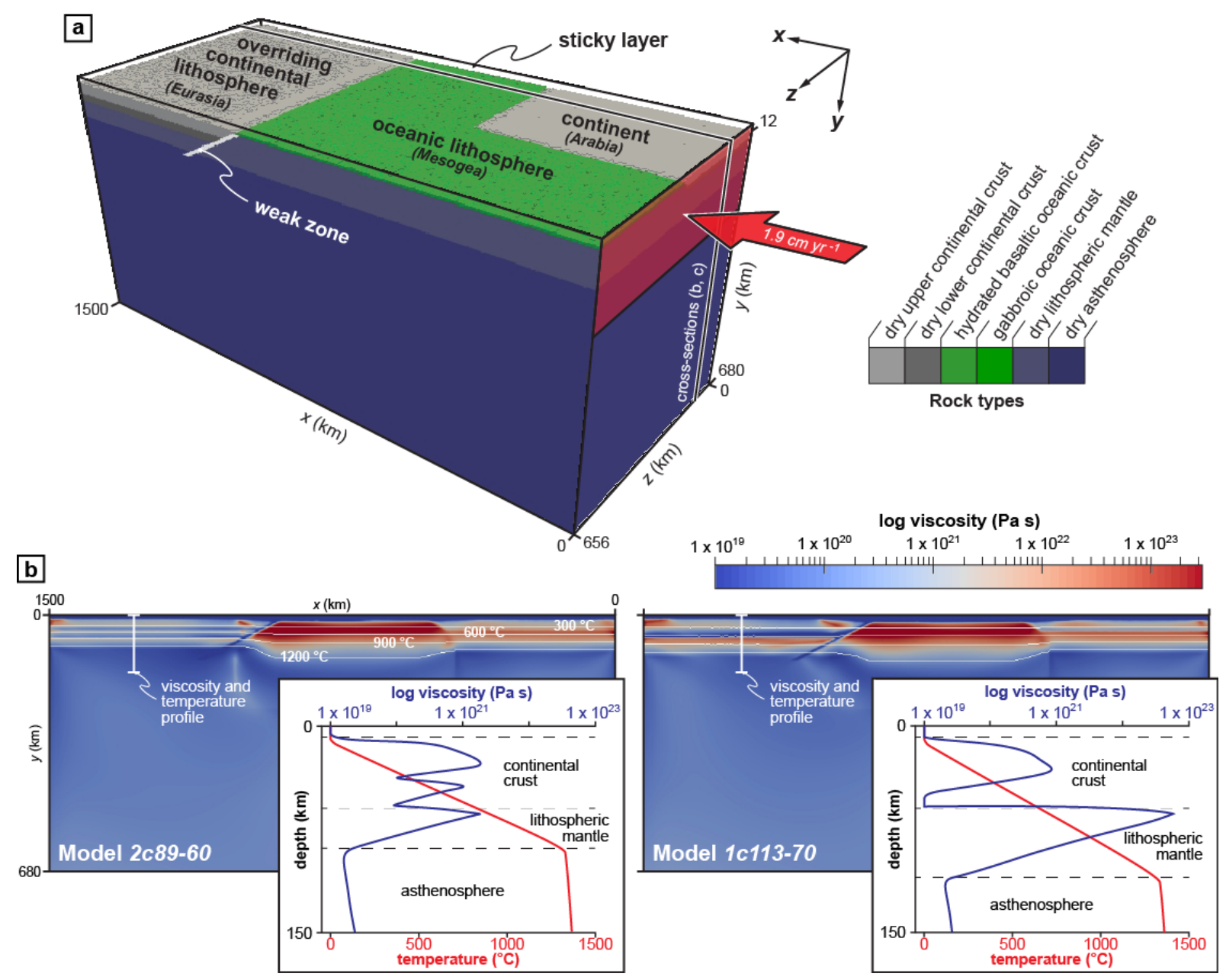

Fig. 3: Initial model setup. (a) 3D model domain with colors representing the different rock types. Air

684 and sea water phases (composing the sticky layer) are cut off for clarity. b) $x-y$ viscosity cross-sections

685 of the initial model domain with a two-layer (left panel) and one-layer (right panel) continental crust.

686 White lines represent $300,600,900$ and $1200{ }^{\circ} \mathrm{C}$ isotherms. Vertical viscosity (blue) and temperature

687 (red) profiles are shown as inset for each model. 

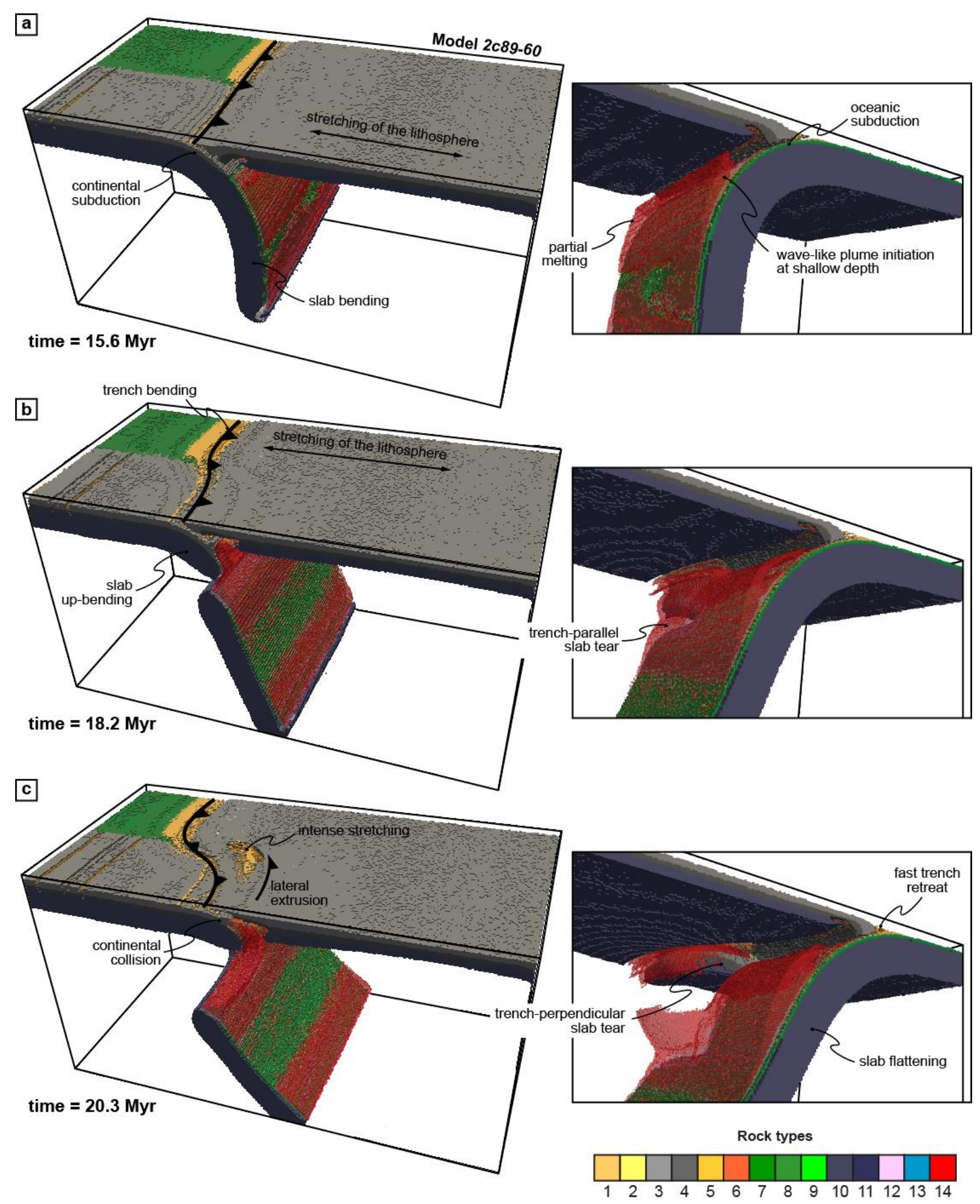

Fig. 4: Evolution of the reference model 2c93-60 (with a two-layer continental crust). (a, b, c) 3D lateral view of the subduction zone (left panels) and zoom on the mantle wedge (right panels) for selected time steps. Colors represent the different rock types: 1 - sediments; 2 - partially molten sediments; 3/4 - dry upper/lower continental crust; 5/6 - hydrated/partially molten continental crust; 7 - dry oceanic crust; 8/9 - hydrated/partially molten oceanic crust; 10 - dry lithospheric mantle; 11 694 dry asthenosphere; $12 / 13$ - hydrated/serpentinized mantle; 14 - partially molten mantle. 695 Asthenosphere and other phases are cut off for clarity. 

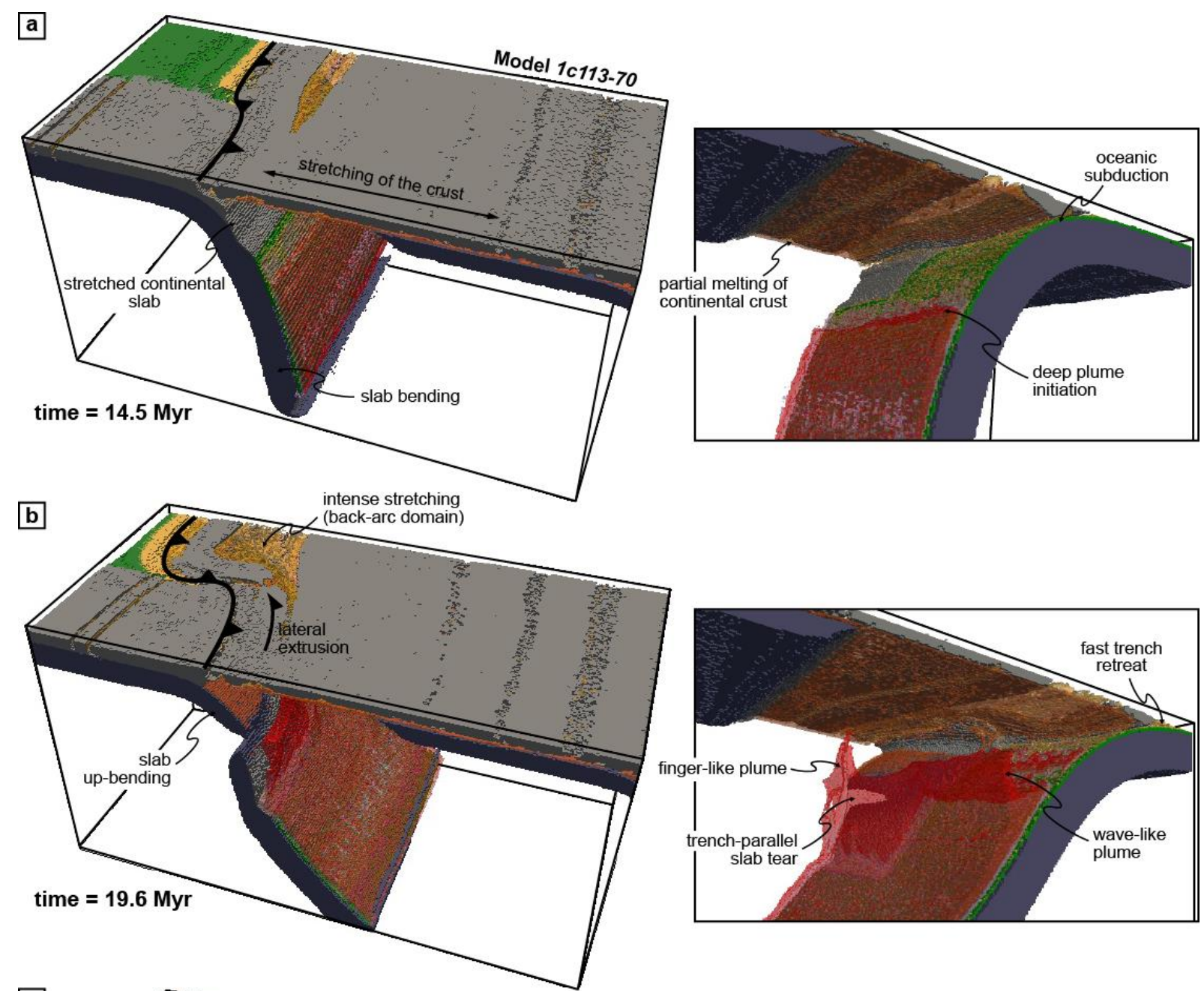

c
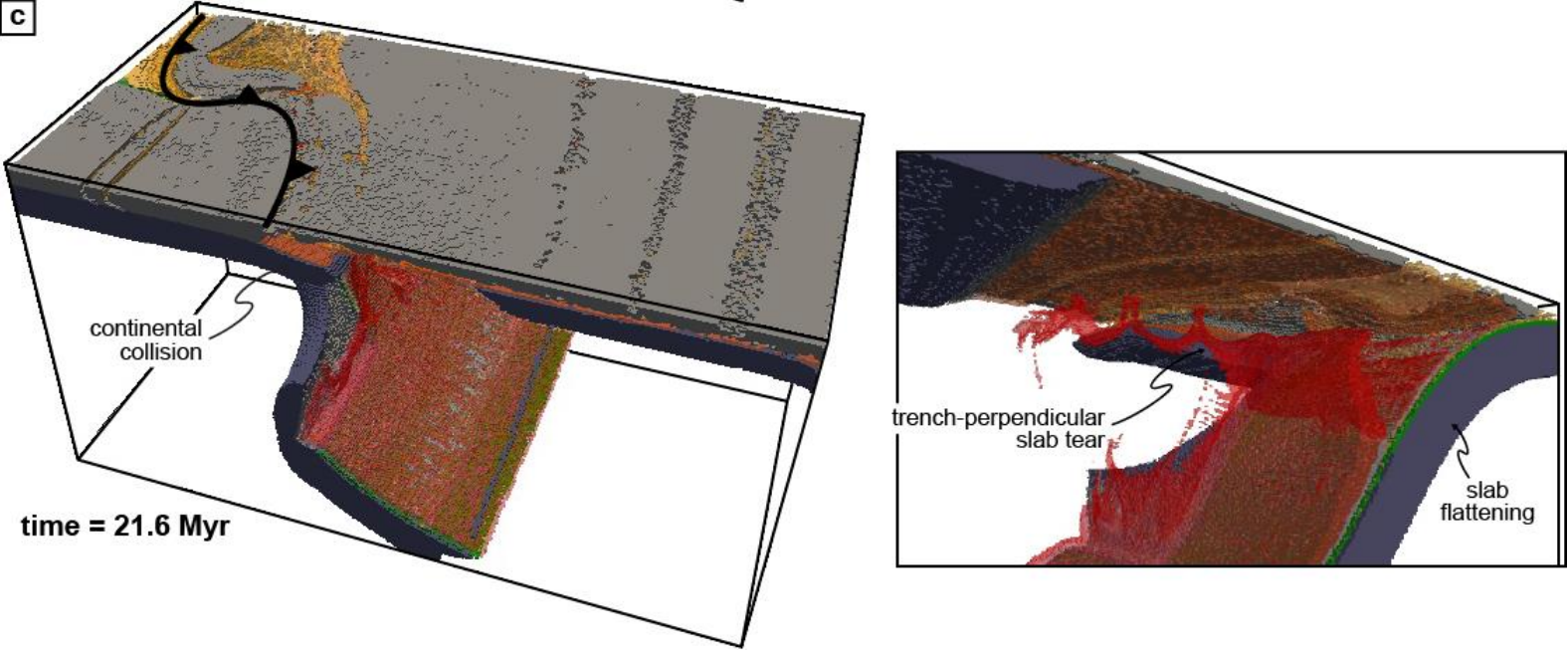

Fig. 5: Evolution of the model 1c113-70 (with a one-layer continental crust). (a, b, c) 3D lateral view of the subduction zone (left panels) and zoom on the mantle wedge (right panels) for selected time steps. Colors represent the different rock types (see Fig. 4 for detailed legend). Asthenosphere and other phases are cut off for clarity. 

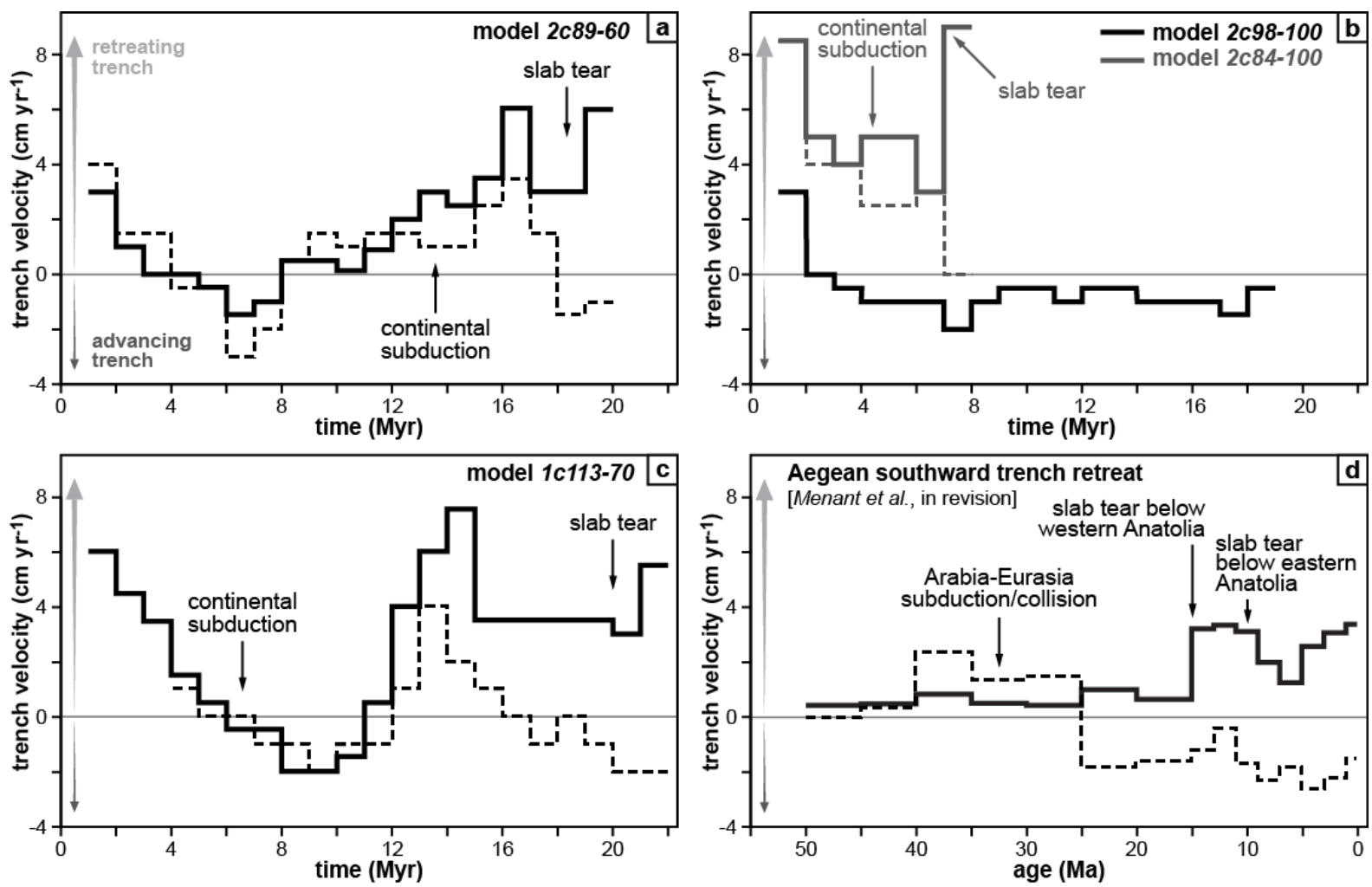

Fig. 6: Time-trench velocity diagram showing the trench migration of both oceanic and oceaniccontinental subduction zones obtained from models $2 c 89-60$ (a), 2c98-100, 2c84-100 (b) and 1c113-70 (c) and from kinematic reconstructions of the eastern Mediterranean region (d) [Menant et al., 2016]. Solid and dashed lines correspond to only oceanic (or Hellenic) and oceanic-continental (or eastern Anatolia) subduction zones, respectively. Positive and negative distances correspond to retreating and advancing trench, respectively. The initiation of continental subduction and slab tearing processes are highlighted for each diagram. 


\section{Model 2c89-60}

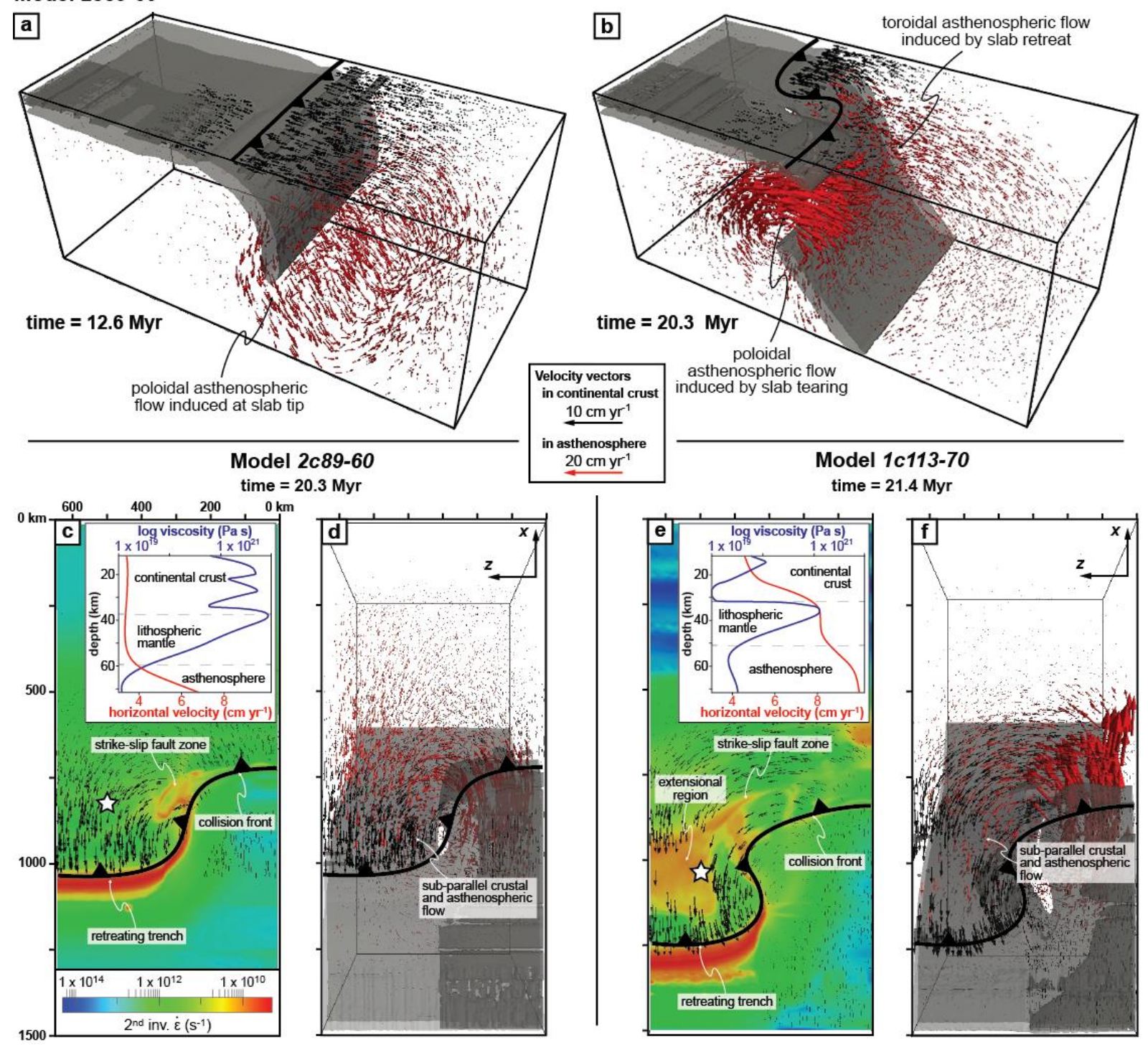

Fig. 7: Asthenospheric and crustal flow evolution and crustal strain rate in performed numerical experiments. $(\mathrm{a}, \mathrm{b}) 3 \mathrm{D}$ view of the subduction zone of model $2 c 93-60$ at two selected time steps (i.e. before and after slab tearing) showing the slab geometry (iso-viscosity contour equal to $10^{23} \mathrm{~Pa} . \mathrm{s}$ ) and velocity vectors in the continental crust (black arrows) and asthenosphere (red arrows). (c, e) $x-z$ plan view of selected time step showing the second invariant of the strain rate tensor in interacting lithospheres of models 2c93-60 and 1c113-70. Vertical viscosity (blue) and velocity (red) profiles are shown as inset for each extensional domain (see the white star for the location of the vertical profile). (d, f) $x-z$ plan view of selected time step showing the velocity vectors in the continental crust and asthenosphere. Scale of velocity vectors is twice larger in continental crust than in asthenosphere. 

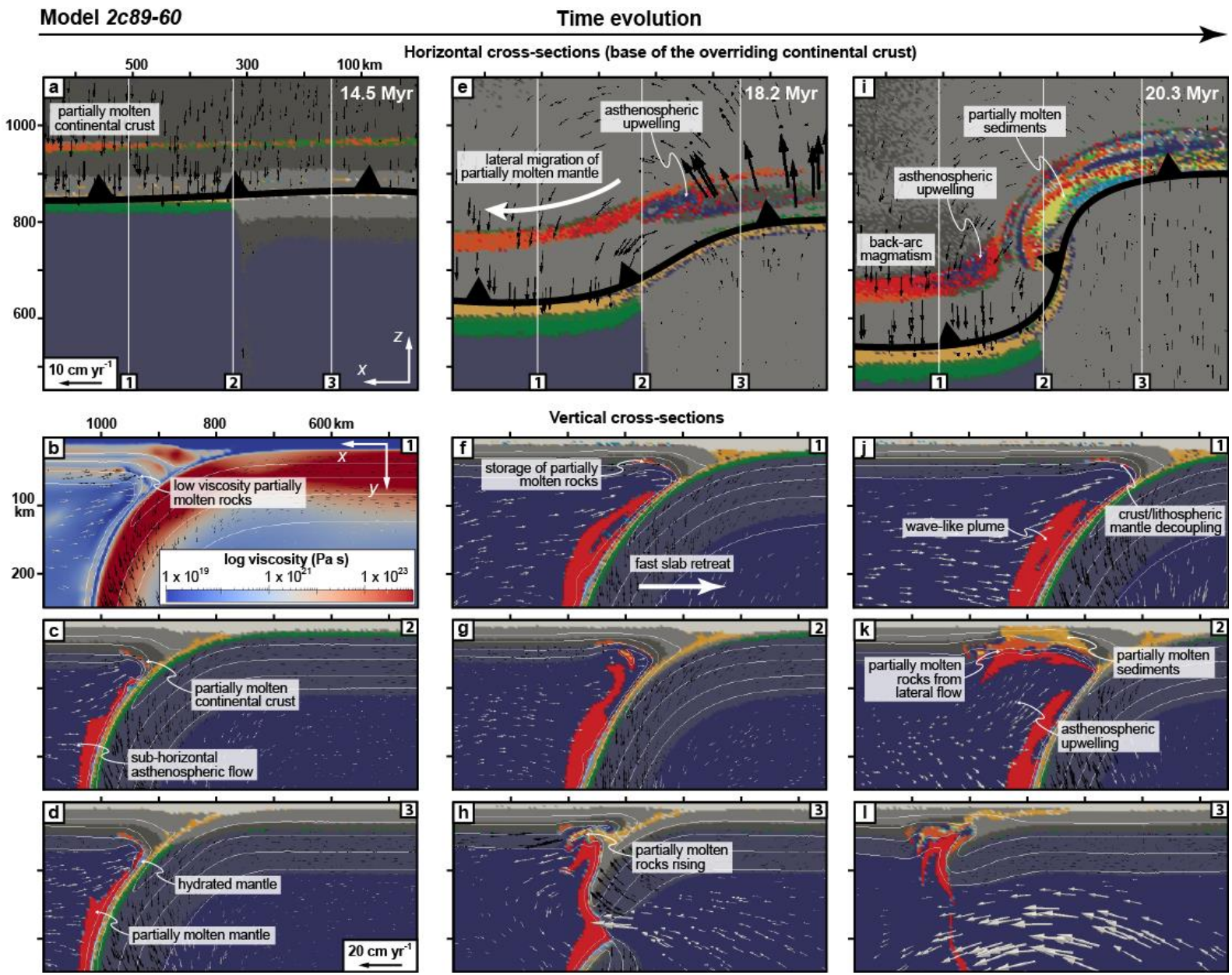

Fig. 8: Evolution of magmatism in reference model 2c93-60. $x$-z plan views (a, e, i) and $x-y$ crosssections (b, c, d, f, g, h, j, k, l) of the subduction zone for selected time steps. Colors represent the

722 different rock types (see Fig. 4 for detailed legend), except for cross-section (b) where the viscosity is mapped. Black and white arrows represent velocity vectors in the continental crust (top panels) or

724 lithospheric mantle (bottom panels) and the asthenosphere, respectively. Scale of velocity vectors is

725 twice larger in top panels than in bottom panels. White lines (bottom panels) represent 300, 600, 900 and $1200^{\circ} \mathrm{C}$ isotherms. 


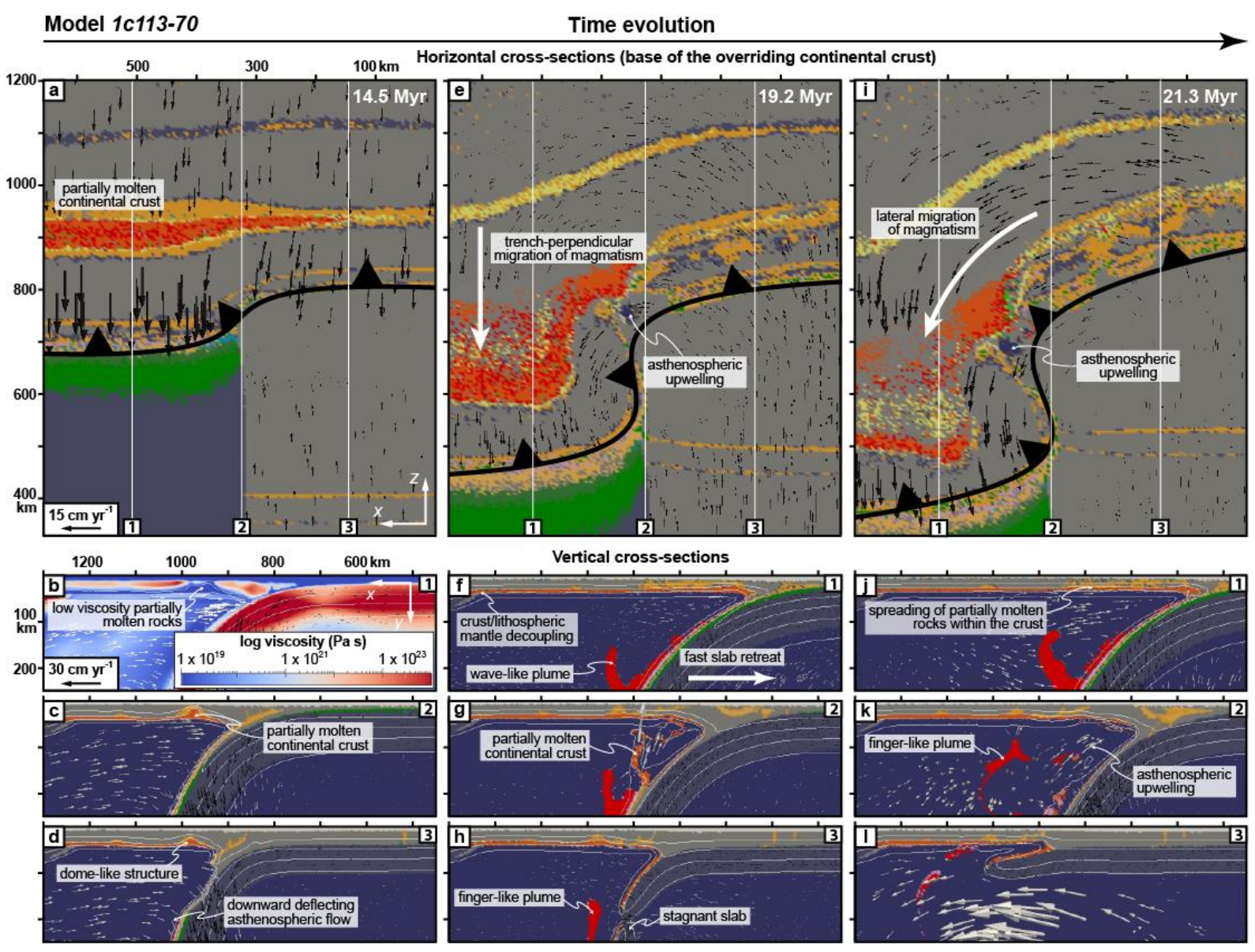

Fig. 9: Evolution of magmatism in model 1c113-70. $x$-z plan views (a, e, i) and $x$ - $y$ cross-sections (b,

$729 \mathrm{c}, \mathrm{d}, \mathrm{f}, \mathrm{g}, \mathrm{h}, \mathrm{j}, \mathrm{k}, \mathrm{l})$ of the subduction zone for selected time steps. Colors represent the different rock

730 types (see Fig. 4 for detailed legend), except for cross-section (b) where the viscosity is mapped. Black

731 and white arrows represent velocity vectors in the continental crust (top panels) or lithospheric mantle

732 (bottom panels) and the asthenosphere, respectively. Scale of velocity vectors is twice larger in top

733 panels than in bottom panels. White lines (bottom panels) represent 300, 600, 900 and $1200{ }^{\circ} \mathrm{C}$

734 isotherms. 

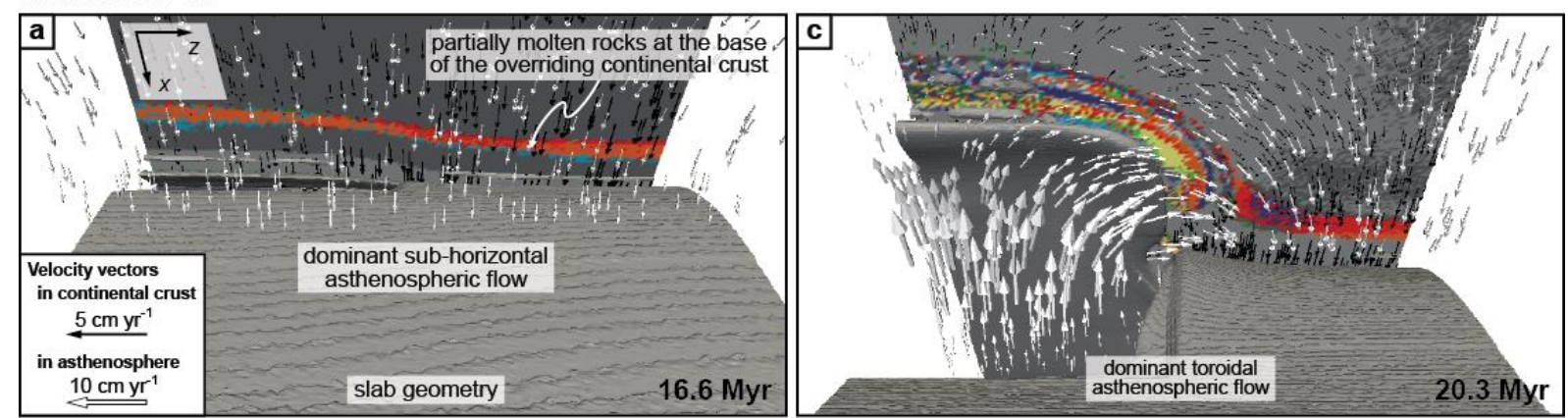

Model 1c113-70
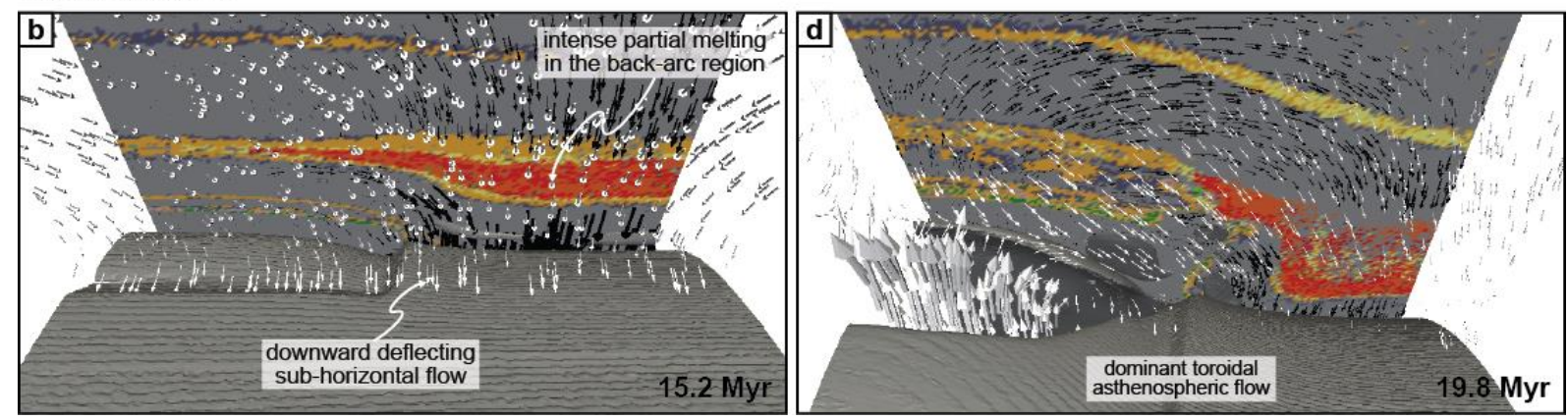

Fig. 10: View from below of the mantle wedge of selected models showing the relation between magmatic evolution at the base of the overriding crust and subduction-related asthenospheric flow for two selected time steps. (a, c) $x-z$ plan view and slab geometry evolution of reference model $2 c 93-60$. (b, d) $x-z$ plan view and slab geometry evolution of reference model 1c113-70. On $x-z$ plan view, colors represent the different rock types (see Fig. 4 for detailed legend). The slab geometry is visualized through an iso-viscosity contour equal to $10^{23} \mathrm{~Pa}$.s. Black and white arrows represent velocity vectors in the continental crust and the asthenosphere, respectively. Scale of velocity vectors is twice larger in continental crust than in asthenosphere. 


\section{Supplementary material}

\section{Numerical approach and governing equations}

\section{Conservation equations}

In our experiments, we model rocks as an incompressible fluid through the 3D mass conservation equation:

751

$$
\nabla \cdot \vec{u}=\frac{\partial v_{x}}{\partial x}+\frac{\partial v_{y}}{\partial y}+\frac{\partial v_{z}}{\partial z}=0
$$

where $v_{x}, v_{y}$ and $v_{z}$ are the components of the velocity vector $\vec{u}$. The momentum of this incompressible fluid thus occurs as a 3D creeping (or laminar) flow meaning that the viscous

$$
\frac{\partial \sigma_{x x}}{\partial x}+\frac{\partial \sigma_{x y}}{\partial y}+\frac{\partial \sigma_{x z}}{\partial z}=\frac{\partial p}{\partial x}
$$

$$
\frac{\partial \sigma_{y x}}{\partial x}+\frac{\partial \sigma_{y y}}{\partial y}+\frac{\partial \sigma_{y z}}{\partial z}=\frac{\partial p}{\partial y}-g \rho
$$

$$
\frac{\partial \sigma_{z x}}{\partial x}+\frac{\partial \sigma_{z y}}{\partial y}+\frac{\partial \sigma_{z z}}{\partial z}=\frac{\partial p}{\partial z}
$$

where $\sigma_{i j}$ are the components of the deviatoric stress tensor, $p$ is the pressure, $g$ is the gravitational acceleration and $\rho$ is the density (Table S1). Finally, heat diffusion in our experiments is solved using the Lagrangian heat conservation equation:

$$
\rho C_{P} \frac{\mathrm{D} T}{\mathrm{D} t}=-\frac{\partial q_{x}}{\partial x}-\frac{\partial q_{y}}{\partial y}-\frac{\partial q_{z}}{\partial z}+H_{r}+H_{a}+H_{s}
$$


where $C_{p}$ is the isobaric heat capacity, $T$ is the temperature, $t$ is the time, $H_{r}$ is the radiogenic heat production, $H_{a}$ is the adiabatic heat production, $H_{s}$ is the shear heating and $q_{x}$, $q_{y}$ and $q_{z}$ are the components of the 3D heat flow solved as:

$$
q_{x}=-k \frac{\partial T}{\partial x}
$$

$$
q_{y}=-k \frac{\partial T}{\partial y}
$$

$$
q_{z}=-k \frac{\partial T}{\partial z}
$$

where $k$ is the thermal conductivity depending on the temperature and rock composition (Table S1). Heat advection is then solved based on marker technics [Gerya and Yuen, 2007]. Surface processes are implemented using a highly simplified gross-scale erosionsedimentation law (see details in Gerya and Yuen [2007]). Considering these physical laws, the I3ELVIS code is able to model multiphase thermo-mechanical flow approximating ductilebrittle deformation of rocks for long time scales.

\section{Fluid/melt dynamics: dehydration, fluid transport, partial melting and melt extraction} computing

In our experiments, each defined lithology can be dry or hydrated, with pressure- and temperature-dependent stable mineralogical water content. Additional porous water content $X_{\mathrm{H}_{2} \mathrm{O}}(\mathrm{wt} . \%)$ is prescribed in the sediments and hydrated oceanic crust and decreases linearly from the surface to $75 \mathrm{~km}$ depth mimicking the effects of low-temperature reactions:

$$
X_{H_{2} O}=X_{H_{2} O(0)}\left(1-\frac{\Delta y}{75}\right)
$$

$$
\text { where } \Delta y \text { is the depth below the surface and } X_{H_{2} O(0)} \text { is the porous water content at the }
$$
surface [Johnson and Pruis, 2003]. During subduction, the local water content of hydrated 
785

sediments and oceanic crust can exceed their maximum water content generating

786 independently moving water markers in the mantle wedge. The $3 \mathrm{D}$ velocity of these markers

787 is then solved according to pressure gradient [Faccenda et al., 2009]:

788

789

790

791

792

$$
A=\frac{\mathrm{v}_{\text {percolation }}}{\mathrm{g}\left(\rho_{\text {mantle }}-\rho_{\text {fluid }}\right)}
$$

where $v_{\text {percolation }}$ is the presumed standard water percolation velocity in the mantle [Nikolaeva et al., 2008] and $\rho_{\text {mantle }}$ is the mantle density. Mobile water is then absorbed by the surrounding mantle or crustal rocks by hydration process depending on pressure, temperature and rock composition (see details in [Zhu et al., 2013]).

$$
\begin{aligned}
& M_{0}=0 \text { at } T<T_{\text {solidus }} \\
& M_{0}=\frac{T-T_{\text {solidus }}}{T_{\text {liquidus }}-T_{\text {solidus }}} \text { at } T_{\text {solidus }}<T<T_{\text {liquidus }}
\end{aligned}
$$

801

where $M_{0}$ is the volumetric fraction of melt with no previous melt extraction, $T_{\text {solidus }}$ and

$$
\text { Partial melting process is also included in our experiments and the volumetric melt fraction }
$$
is calculated for all rocks, excepted hydrated mantle, as:$$
M_{0}=1 \text { at } T>T_{\text {liquidus }}
$$

$T_{\text {liquidus }}$ are, respectively, the solidus and liquidus temperatures depending on the pressure and 
rock composition (Table S1). For the hydrated mantle, the degree of partial melting also depends on the water content according to the parameterization of Katz et al. [2003] that is constrained by thermodynamic experimental modeling. Resulting partially molten rocks can then undergo a succession of melt extraction episodes depending on their melt extraction threshold $M_{\max }$ and non-extractable melt fraction $M_{\min }$, both equal to $1 \%$. Only the exceeding volumetric melt fraction (i.e. $>1 \%$ ) is then extracted from partially molten rocks and tracked by partially molten rock markers. For each extraction episode, the melt fraction $M_{\text {ext }}$ recorded in the partially molten rock markers is calculated as:

$$
M_{\text {ext }}=M-M_{\min }
$$

$$
\text { where } M \text { is the volumetric melt fraction in partially molten rock which accounts for }
$$
previous extraction episodes and is calculated as:

$$
M=M_{0}-\sum M_{\text {ext }}
$$

$$
\text { where } \sum M_{e x t} \text { is the total melt fraction from previous extraction episodes. } M \text { varies then }
$$
dynamically (Eqs. 8 and 10) until remaining solid rock is considered as refractory (i.e. unable to undergo additional partial melting) when $\sum M_{\text {ext }}>M_{0}$. Partially molten rock markers resulting from these extraction episodes are then instantaneously transmitted to the surface as free melt is assumed to propagate upward much faster than rocks deform [Hawkesworth, 1997]. At the surface, these markers create volcanic rocks characterized by their volume and composition (i.e. partially molten source).

\section{Rock properties and rheology}

The physical properties of rocks used in our experiments are given in Table S1. Among them, the density of solid rocks $\rho_{\text {solid }}$ is calculated as: 


$$
\rho_{\text {solid }}=\rho_{0 \text { solid }}(1-\alpha(T-298))(1+\beta(p-0.1))
$$
expansion and compressibility of rock. For partially molten rocks, their effective density $\rho_{\text {eff }}$ is calculated as:

$$
\rho_{\text {eff }}=\rho_{\text {solid }}\left(1-M+M \frac{\rho_{\text {omolten }}}{\rho_{\text {osolid }}}\right)
$$

where $\rho_{\text {Omolten }}$ is the standard density of molten rock. Non-Newtonian visco-plastic

$844 \quad \eta_{\text {creep }} \leq \frac{\sigma_{y i e l d}}{2 \dot{\varepsilon}_{I I}}$ rheologies used in our experiments are implemented by both ductile and brittle/plastic experimentally constrained laws. Thus, the effective viscosity for dislocation creep depending on the strain rate, pressure and temperature is calculated as:

$$
\eta_{\text {creep }}=\dot{\varepsilon}_{I I}^{\frac{1-n}{n}} A_{D}^{\frac{-1}{n}} \exp \left(\frac{E+P V}{n R T}\right)
$$

where $\dot{\varepsilon}_{I I}$ is the second invariant of the strain rate tensor, $n$ (creep exponent), $A_{D}$ (preexponential factor), $E$ (activation energy) and $V$ (activation volume) are experimentally determined parameters specific to applied viscous flow law (i.e. wet quartzite, plagioclase $\left(\mathrm{An}_{75}\right)$, dry olivine and wet olivine flow laws; Table S1) [Ranalli, 1995]. $R$ is the gas constant. This ductile behavior is limited with a brittle/plastic one, implemented by using the DruckerPrager criterion $\sigma_{\text {yield }}($ i.e. plastic strength) [Ranalli, 1995] as:

where $\sigma_{\text {yield }}$ is calculated as:

$$
\sigma_{y i e l d}=c+p \sin (\varphi)
$$


847 where $c$ is the cohesion of the rock and $\varphi$ is the effective internal friction angle depending 848 on the fluid and melt contents (see details in Gerya and Meilick [2011]). The lower and upper 849 cut-off values for the viscosities of all rock compositions in our numerical experiments are $850 \quad 10^{19}$ and $10^{24} \mathrm{~Pa} \mathrm{~s}$, respectively. 


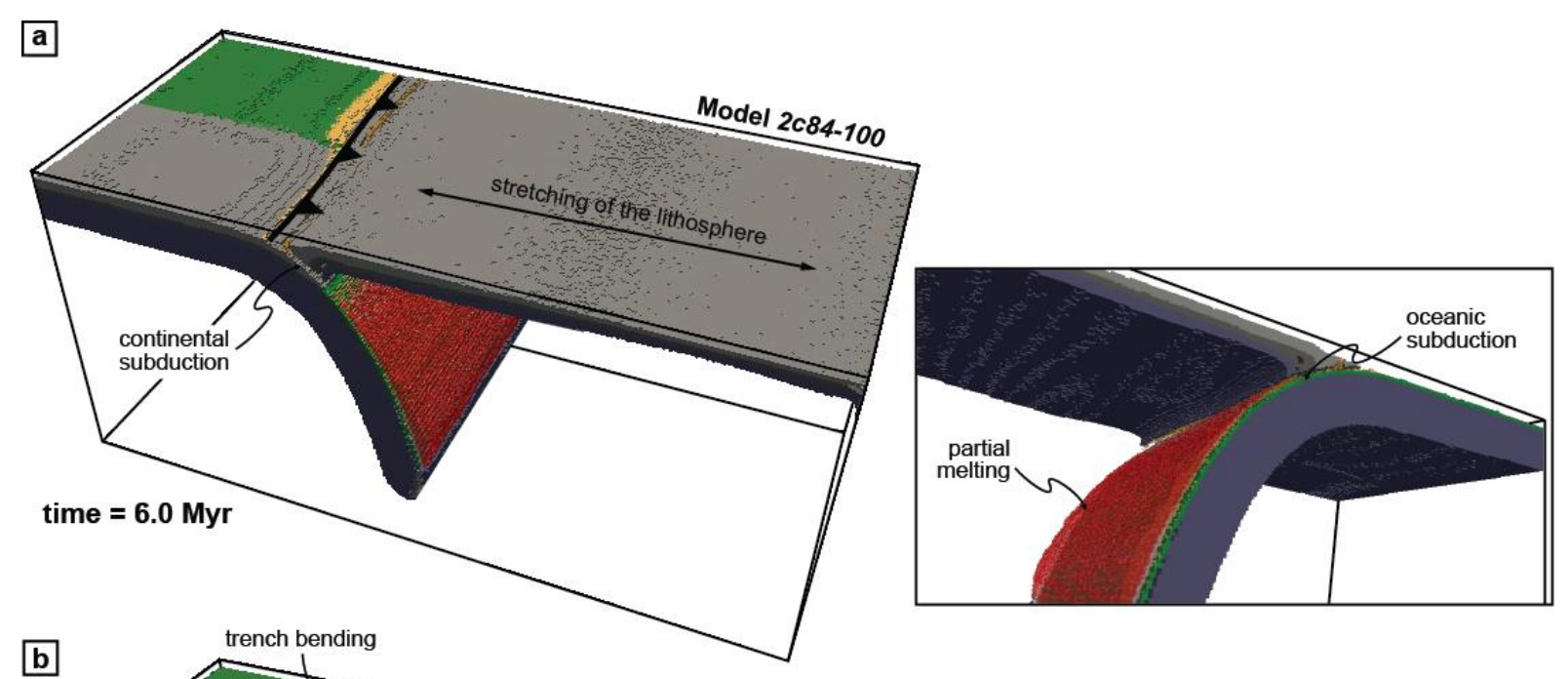

b

b trench bending
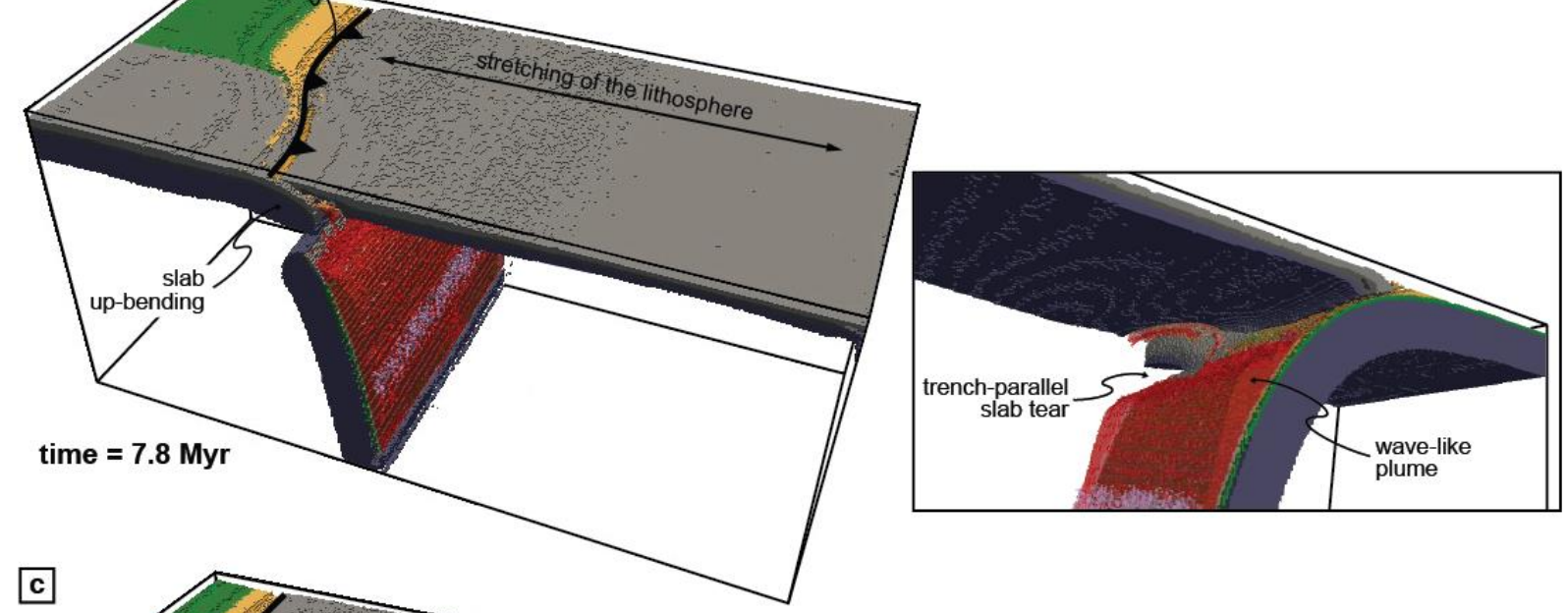

c
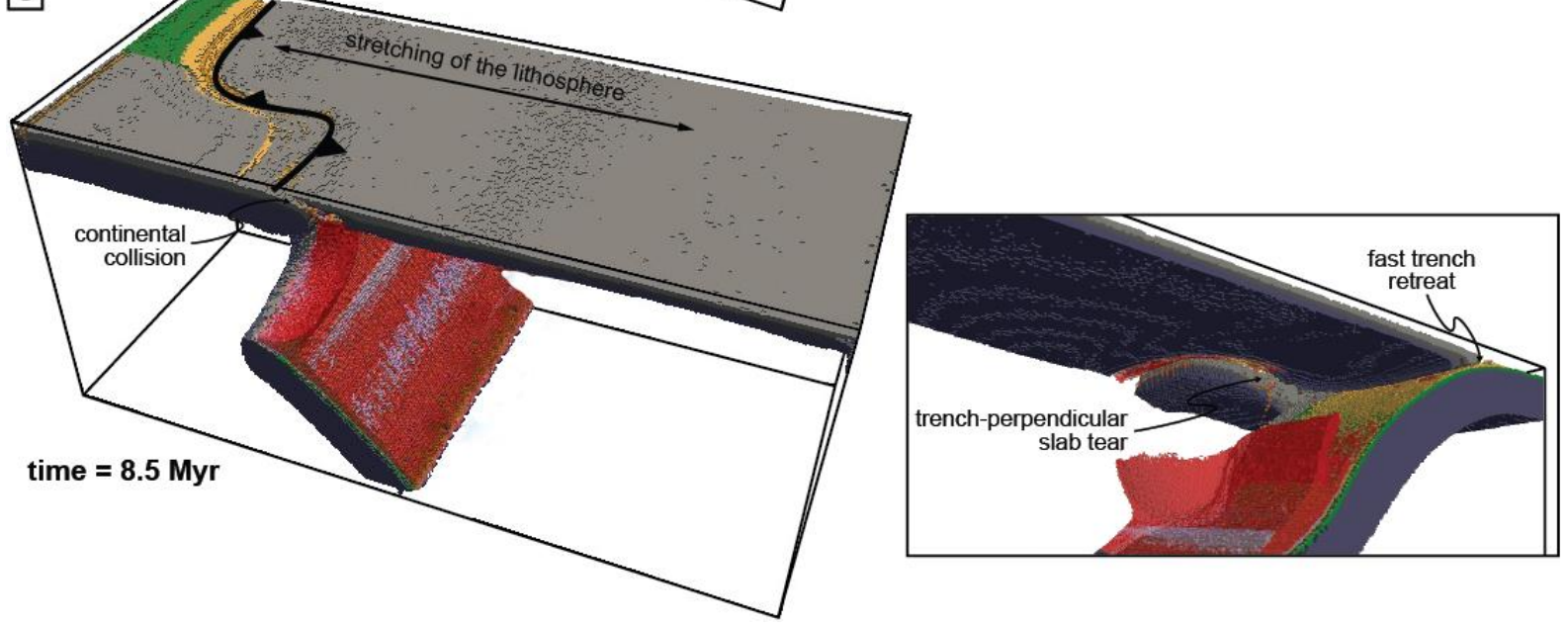

Fig. S1: Evolution of the model 2c84-100. a, b, c) 3D lateral view of the subduction zone (left panels) and zoom on the mantle wedge (right panels) for selected time steps. Colors represent the different rock types (see Fig. 4 for detailed legend). Asthenosphere and other phases are cut off for clarity. 
a

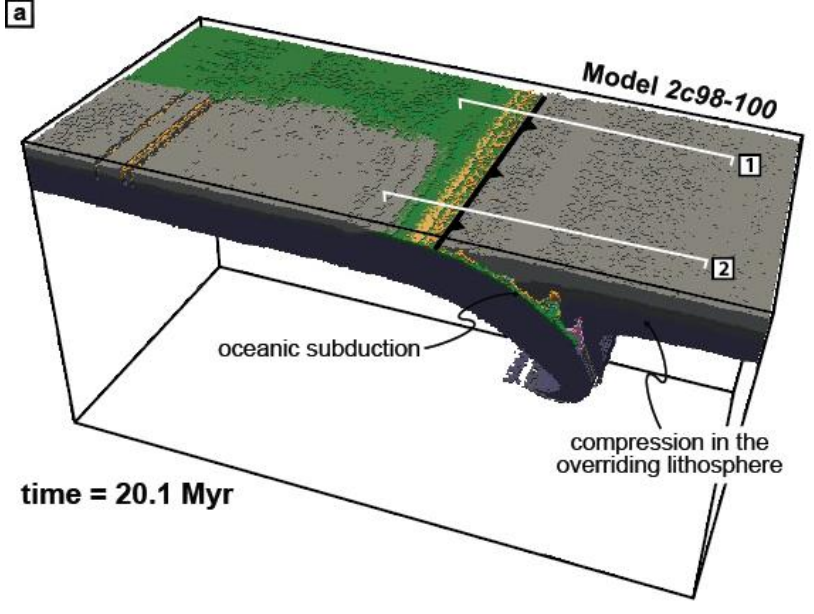

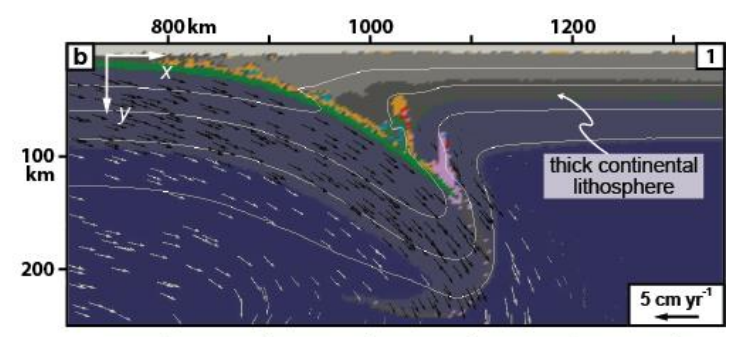

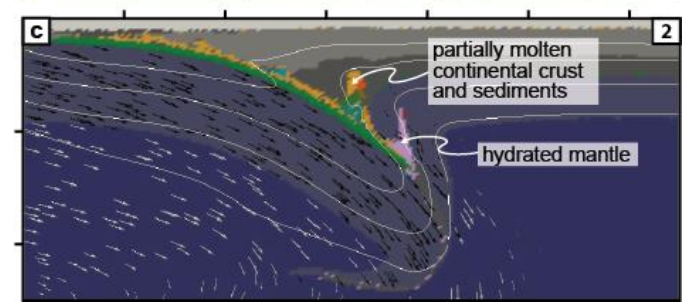

860 Fig. S2: Subduction geometry of the model $2 c 98-100$ displaying a relatively strong coupling between 861 both interacting lithospheres. a) 3D lateral view of the subduction zone highlighting the compressional 862 tectonics in the overriding continental lithosphere. b, c) $x-y$ cross-sections of the subduction zone 863 highlighting the restrained magmatic activity in the mantle wedge and the low velocity field in both 864 the subducting lithosphere and the underlying asthenosphere (see Fig. 4 for detailed legend). 


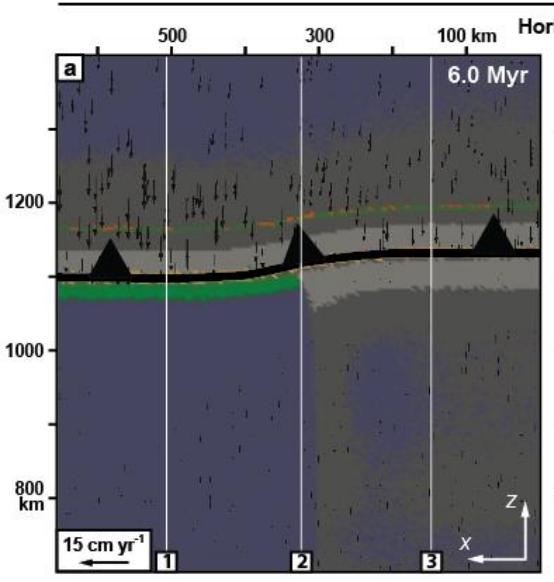

1200
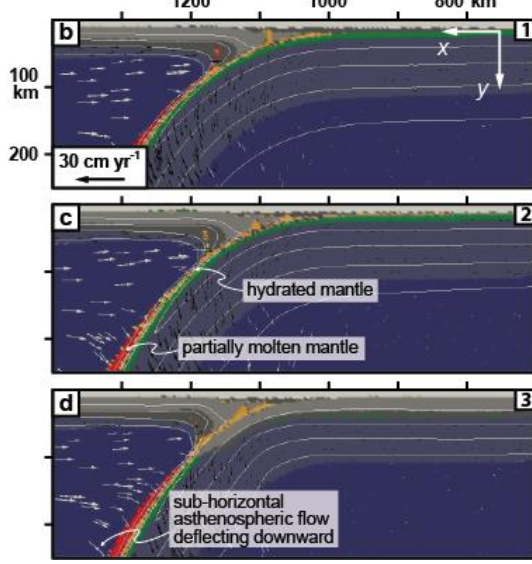

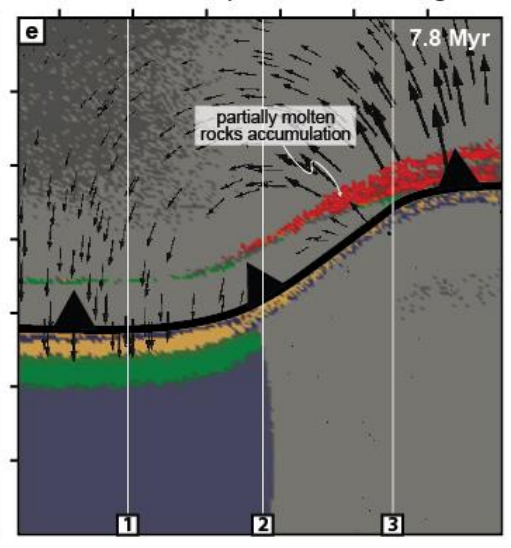

Vertical cross-sections
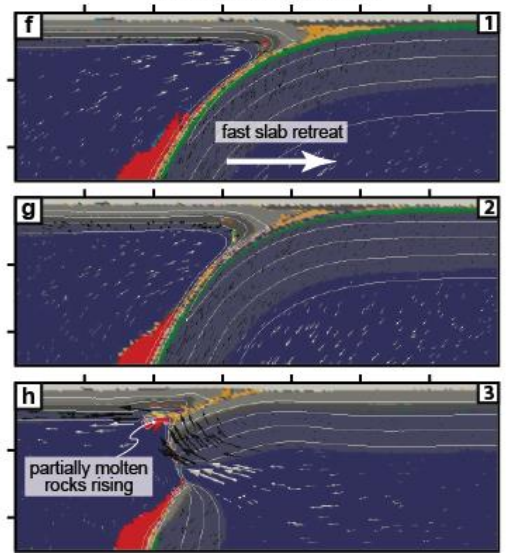
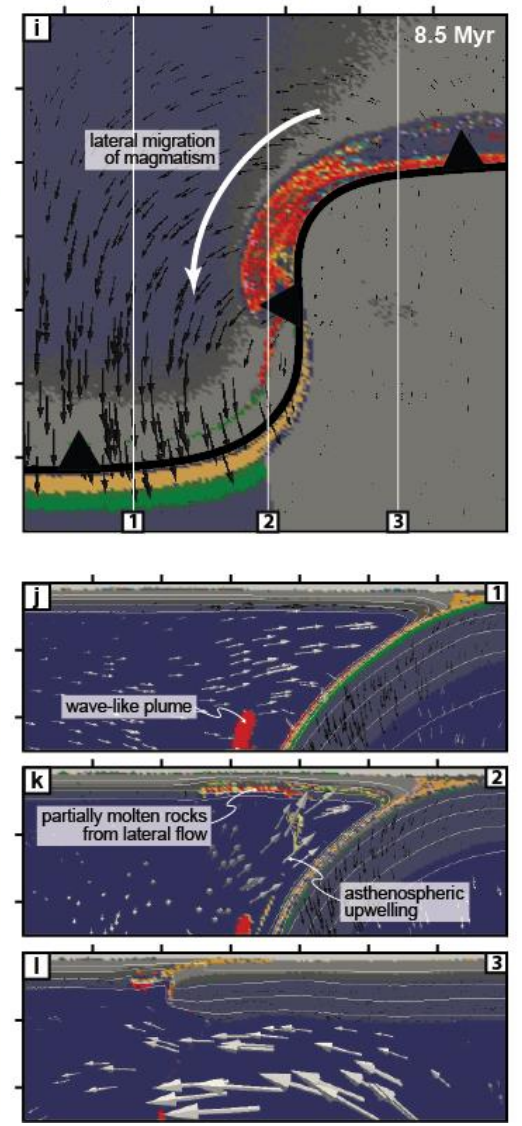

Fig. S3: Evolution of magmatism in model 2c84-100. $x$-z plan views (a, e, i) and $x$ - $y$ cross-sections (b,

$868 \mathrm{c}, \mathrm{d}, \mathrm{f}, \mathrm{g}, \mathrm{h}, \mathrm{j}, \mathrm{k}, \mathrm{l})$ of the subduction zone for selected time steps. Colors represent the different rock 869 types (see Fig. 4 for detailed legend). Black and white arrows represent velocity vectors in the 870 continental crust (top panels) or lithospheric mantle (bottom panels) and the asthenosphere, 871 respectively. Scale of velocity vectors is twice larger in top panels than in bottom panels. White lines 872 (bottom panels) represent $300,600,900$ and $1200{ }^{\circ} \mathrm{C}$ isotherms. 


\section{Supplementary tables}

875

\begin{tabular}{|c|c|c|c|c|c|c|c|c|c|c|c|c|}
\hline Material & $(\mathrm{kg} \mathrm{m}-3)$ & $\begin{array}{l}\text { Isobaric heat } \\
\text { capacity } C_{p} \\
\left(\mathrm{~J} \mathrm{~kg}^{-1} \mathrm{~K}^{-1}\right)\end{array}$ & $\begin{array}{l}\text { Thermal } \\
\text { conductivity } k \\
\left(\mathrm{~W} \mathrm{~m}^{-1} \mathrm{~K}^{-1}\right)\end{array}$ & $\begin{array}{l}\text { Radiogenic } \\
\text { heat production } \\
H_{r} \\
\left(\mathrm{~mW} \mathrm{~m}^{-3}\right)\end{array}$ & (K) & $\begin{array}{l}T_{\text {liquidus }} \\
\text { (K) }\end{array}$ & $\begin{array}{l}\text { Thermal } \\
\text { expansion } \\
\alpha \\
\left(\mathrm{K}^{-1}\right)\end{array}$ & $\begin{array}{l}\text { Compres- } \\
\text { sibility } \beta \\
\left(\mathrm{MPa}^{-1}\right)\end{array}$ & Viscous flow law & $\begin{array}{l}\text { Creep } \\
\text { exponent } \\
n\end{array}$ & $\begin{array}{l}\text { Activation } \\
\text { energy } E \\
\left(\mathrm{~kJ} \mathrm{~mol}^{-1}\right)\end{array}$ & $\begin{array}{l}\text { Activation } \\
\text { volume } V \\
\left(\mathrm{~cm}^{3} \mathrm{~mol}^{-1}\right)\end{array}$ \\
\hline Air & 1 & 100 & 20 & 0 & & & 0 & 0 & Air & 1 & 0 & 0 \\
\hline Sea water & 1000 & 3330 & 20 & 0 & & & 0 & 0 & Water & 1 & 0 & 0 \\
\hline Sediments & $\begin{array}{l}2600 \text { (solid) } \\
2400 \text { (molten) }\end{array}$ & $\begin{array}{l}1000 \\
1500\end{array}$ & $0.64+807 /(T-77)$ & 2 & $\begin{array}{l}889+179 /(P+54)+20200 /(P+54)^{2} \text { at } P<1200 \mathrm{MPa} \\
831+0.06 P \text { at } P>1200 \mathrm{MPa}\end{array}$ & $1262+0.09 P$ & $3 \times 10^{-5}$ & $3 \times 10^{-3}$ & wet quartzite & $\begin{array}{l}2.3 \\
1\end{array}$ & 154 & 0 \\
\hline $\begin{array}{l}\text { Upper } \\
\text { continental } \\
\text { crust }\end{array}$ & $\begin{array}{l}2750 \text { (solid) } \\
2700 \text { (hydrated) } \\
2400 \text { (molten) }\end{array}$ & 1000 & $0.64+807 /(T-77)$ & 1 & $\begin{array}{l}889+179 /(P+54)+20200 /(P+54)^{2} \text { at } P<1200 \mathrm{MPa} \\
831+0.06 \mathrm{P} \text { at } \mathrm{P}>1200 \mathrm{MPa}\end{array}$ & $1262+0.09 P$ & $3 \times 10^{-5}$ & $3 \times 10^{-3}$ & wet quartzite & 2.3 & 154 & 0 \\
\hline $\begin{array}{l}\text { Lower } \\
\text { continental } \\
\text { crust }\end{array}$ & $\begin{array}{l}2950 \text { (solid) } \\
2900 \text { (hydrated) } \\
2400 \text { (molten) }\end{array}$ & $\begin{array}{l}1000 \\
1500\end{array}$ & $0.64+807 /(T-77)$ & 0.5 & $1327.15+0.0906 P$ & $1423+0.105 P$ & $3 \times 10^{-5}$ & $3 \times 10^{-3}$ & wet quartzite & 1 & 0 & 0 \\
\hline $\begin{array}{l}\text { Oceanic } \\
\text { crust }\end{array}$ & $\begin{array}{l}3000 \text { (solid) } \\
3000 \text { (hydrated) } \\
2900 \text { (molten) }\end{array}$ & $\begin{array}{l}1000 \\
1500\end{array}$ & $1.18+474 /(T-77)$ & 0.25 & $\begin{array}{l}1327.15+0.0906 P \\
973-70400 /(P+54)+778 \times 10^{5} /(P+354)^{2} \\
\text { at } P<1600 \mathrm{MPa} ; \\
935+0.0035 P+6.2 \times 10^{-6} \text { at } P>1600 \mathrm{MPa}\end{array}$ & $1423+0.105 P$ & $3 \times 10^{-5}$ & $3 \times 10^{-3}$ & $\begin{array}{l}\text { Plagiocalse }\left(\mathrm{An}_{75}\right) \\
\text { wet quartzite } \\
\text { Plagiocalse }\left(\mathrm{An}_{75}\right)\end{array}$ & $\begin{array}{l}3.2 \\
2.3 \\
1\end{array}$ & $\begin{array}{l}238 \\
154 \\
0\end{array}$ & 0 \\
\hline Mantle & $\begin{array}{l}3300 \text { (solid) } \\
3300 \text { (hydrated/ } \\
\text { serpentinized) } \\
2900 \text { (molten) }\end{array}$ & $\begin{array}{l}1000 \\
1500\end{array}$ & $0.73+1293 /(T-77)$ & 0.022 & $P-T-H_{2} O$ dependent melting model of Katz et a & . (2003) & $3 \times 10^{-5}$ & $3 \times 10^{-3}$ & $\begin{array}{l}\text { dry olivine } \\
\text { wet olivine } \\
\text { dry olivine }\end{array}$ & 3.5 & $\begin{array}{l}470 \\
0\end{array}$ & 0.8 \\
\hline Weak zone & 3300 & 1000 & $0.73+1293 /(T-77)$ & 0.05 & $\mathrm{n} / \mathrm{a}$ & $\mathrm{n} / \mathrm{a}$ & $3 \times 10^{-5}$ & $3 \times 10^{-3}$ & wet olivine & 4 & 470 & 0.8 \\
\hline
\end{tabular}

876

877 Table S1: Material properties used in the numerical experiments. See details in the text. 


\begin{tabular}{|c|c|c|c|c|c|}
\hline \multirow{2}{*}{\multicolumn{2}{|c|}{$\begin{array}{l}\text { Models with two-layer } \\
\text { continental crust }\end{array}$}} & \multicolumn{4}{|c|}{ thermal age of the oceanic lithosphere } \\
\hline & & \multirow{2}{*}{$\frac{40 \mathrm{Ma}}{2 \mathrm{c} 84-40}$} & \multirow{2}{*}{$\frac{60 \mathrm{Ma}}{2 \mathrm{c} 84-60}$} & \multirow{2}{*}{$\begin{array}{c}80 \mathrm{Ma} \\
2 \mathrm{c} 84-80\end{array}$} & \multirow{2}{*}{$\frac{100 \mathrm{Ma}}{2 \mathrm{c84}-100}$} \\
\hline 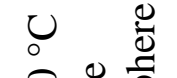 & $84 \mathrm{~km}$ & & & & \\
\hline$\stackrel{m}{\Xi}$. & $89 \mathrm{~km}$ & $2 c 89-40$ & $2 c 89-60$ & $2 c 89-80$ & $2 c 89-100$ \\
\hline 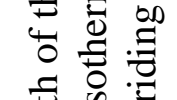 & $93 \mathrm{~km}$ & $2 c 93-40$ & $2 c 93-60$ & $2 c 93-80$ & $2 c 93-100$ \\
\hline 8 & $98 \mathrm{~km}$ & $2 c 98-40$ & $2 c 98-60$ & $2 \mathrm{c} 98-80$ & 2c98-100 \\
\hline
\end{tabular}

878

\begin{tabular}{|c|c|c|c|c|}
\hline \multirow{2}{*}{\multicolumn{2}{|c|}{$\begin{array}{l}\text { Models with one-layer } \\
\text { continental crust }\end{array}$}} & \multicolumn{3}{|c|}{$\begin{array}{l}\text { thermal age of the oceanic } \\
\text { lithosphere }\end{array}$} \\
\hline & & $60 \mathrm{Ma}$ & $70 \mathrm{Ma}$ & $80 \mathrm{Ma}$ \\
\hline 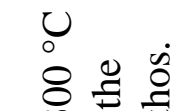 & $111 \mathrm{~km}$ & $1 \mathrm{c} 111-60$ & $1 \mathrm{c} 111-70$ & $1 \mathrm{c} 111-80$ \\
\hline$\stackrel{0}{\Xi} \stackrel{00}{\Xi}$ & $113 \mathrm{~km}$ & $1 \mathrm{c} 113-60$ & 1c113-70 & $1 \mathrm{c} 113-80$ \\
\hline$\frac{\overrightarrow{0}}{0} \cdot \frac{n}{0}$ & $115 \mathrm{~km}$ & $1 \mathrm{c} 115-60$ & $1 \mathrm{c} 115-70$ & $1 \mathrm{c} 115-80$ \\
\hline
\end{tabular}

879

880

881 Table S2: Range of performed models with variations in the continental crust structure and

882 geothermal gradient in the continental and oceanic lithospheres leading to explore the role of

883 lithosphere rheology on subduction dynamics and magmatic evolution. The overriding lithosphere in

884 dark grey, light grey and white models undergoes, respectively, a compressional, minor extensional

885 and major extensional tectonics. Models in bold are described in the text.

886 